\title{
Perceptions of calf pool participants toward West Virginia calf pool organizations
}

\author{
Carrie M. Stemple \\ West Virginia University
}

Follow this and additional works at: https://researchrepository.wvu.edu/etd

\section{Recommended Citation}

Stemple, Carrie M., "Perceptions of calf pool participants toward West Virginia calf pool organizations" (2007). Graduate Theses, Dissertations, and Problem Reports. 2526.

https://researchrepository.wvu.edu/etd/2526

This Thesis is protected by copyright and/or related rights. It has been brought to you by the The Research Repository @ WVU with permission from the rights-holder(s). You are free to use this Thesis in any way that is permitted by the copyright and related rights legislation that applies to your use. For other uses you must obtain permission from the rights-holder(s) directly, unless additional rights are indicated by a Creative Commons license in the record and/ or on the work itself. This Thesis has been accepted for inclusion in WVU Graduate Theses, Dissertations, and Problem Reports collection by an authorized administrator of The Research Repository @ WVU. For more information, please contact researchrepository@mail.wvu.edu. 


\title{
Perceptions of Calf Pool Participants toward \\ West Virginia Calf Pool Organizations
}

\author{
Carrie M. Stemple
}

Thesis submitted to the Davis College of Agriculture, Forestry and Consumer Sciences at West Virginia University in partial fulfillment of the requirements for the degree of

\section{Master of Science} in

Agricultural and Extension Education

\author{
Stacy A. Gartin, Ph.D., Chair \\ Harry N. Boone, Jr., Ph.D. \\ Deborah A. Boone, Ph.D.
}

Division of Resource Management

Morgantown, WV

2007 


\section{ABSTRACT \\ Perceptions of Calf Pool Participants \\ toward \\ West Virginia Calf Pool Organizations}

Carrie M. Stemple

The purpose of this study was to determine perceptions of West Virginia calf pool producers with their local organization. This study was a descriptive survey research conducted with West Virginia calf pool producers who participated in a calf pool in 2005 and/or 2006. The majority of participants in the study reported that they were satisfied with the calf pool organizations, and would continue to participate. Over half reported that they planned to increase their production within five years in order to market more calves through the calf pool. The average calf pool producer in West Virginia is over 50 years of age, raises 56 calves on his farm and markets 36 of them through WV calf pools. 


\section{ACKNOWLEDGEMENTS}

I hope that this is not the only occasion I get to thank everyone who has supported me in this endeavor. However, I would like to take the opportunity to put it in black and white.

First and foremost, I want to thank my parents, Bryan and Connie Stemple, for instilling in me a great love of farming and all things agriculture. You have never stopped encouraging me, and I am grateful for that. Every bit of my success is also yours.

My fiancé, David: Thank you for the hours of "quality time" you contributed, helping with the mailings, your enthusiasm when the surveys came back, and listening to me read the same line twenty times before I was happy with it. Although you couldn't help but lend an ear, I appreciated your encouraging words when I badly needed them. Thank you for supporting me on this bumpy ride.

Dr. Harry Boone- From teaching me the basics of research down to the final analysis of data, you were critical to this project. I can't thank you enough for your objective views and "hints" when I didn't know (or just forgot that I knew!) the answers. You are truly a solid rock in the boiling waters of graduate school, and I thank you for that.

Dr. Debby Boone- As the resident "mother" of the Ag Ed Department, you provided the right amount of gentle guidance. Thank you for sharing with me the benefit of your experiences and for lending confidence when I couldn't find mine.

Dr. Stacy Gartin- I want to thank you, as my advisor, for providing me with many challenges during this undertaking. Overcoming those challenges made me a stronger person, and that will last beyond the completion of graduate school. Thank you for all you've done throughout my college career, I am certain that without your support I would not have achieved those academic goals that I set in Ag Communications all those semesters ago. 


\section{TABLE OF CONTENTS}

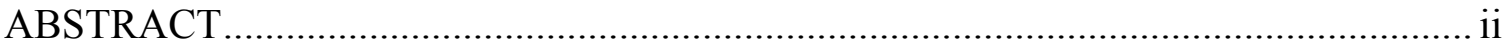

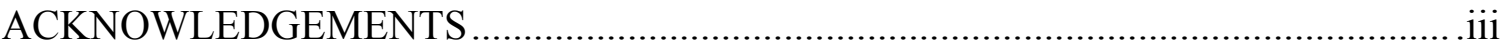

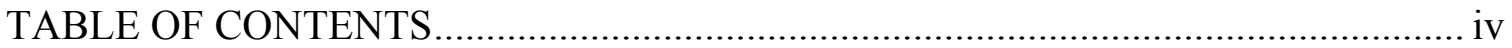

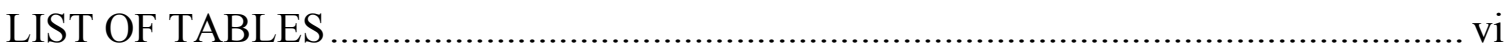

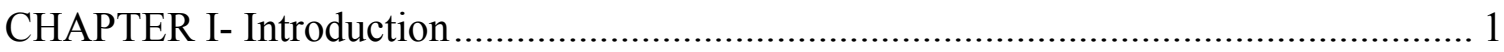

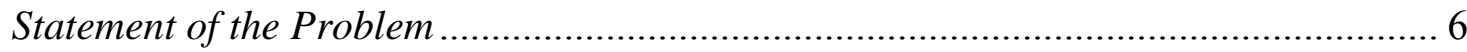

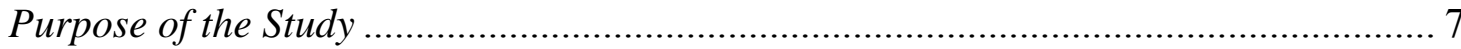

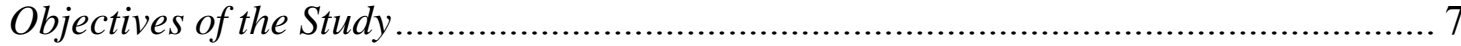

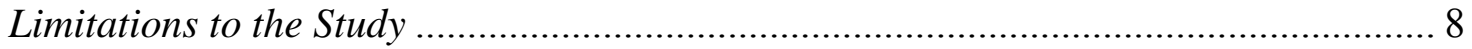

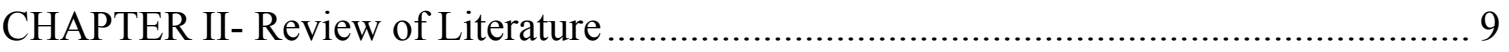

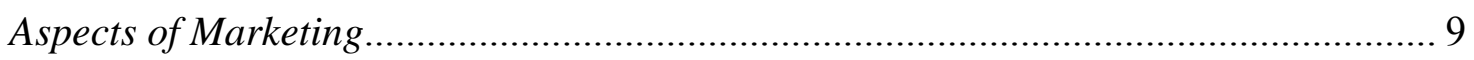

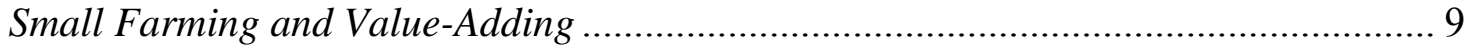

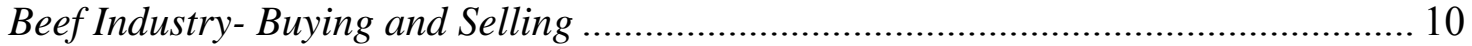

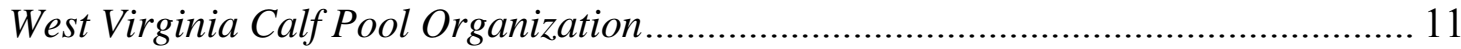

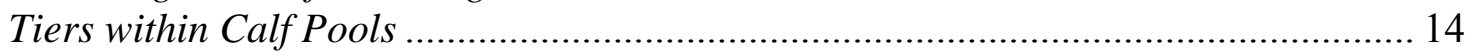

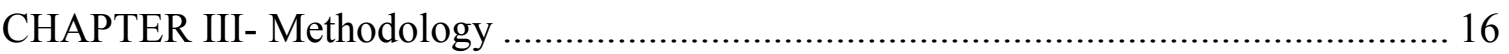

Statement of the Problem ................................................................................... 16

Purpose of the Study ........................................................................................ 16

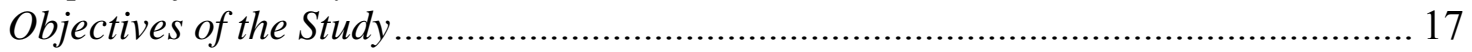

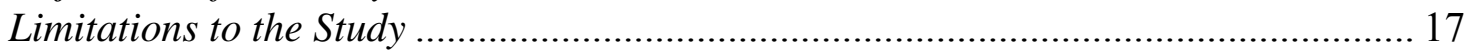

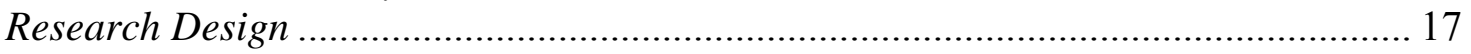

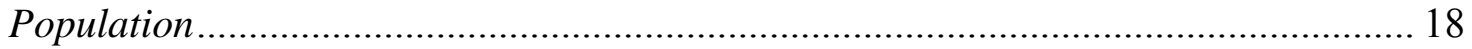

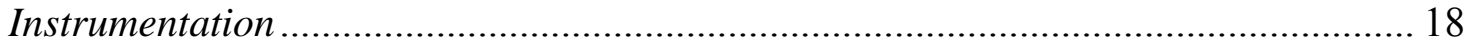

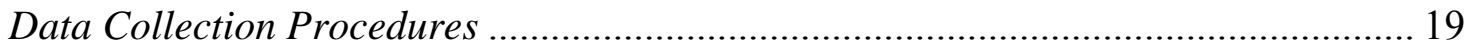

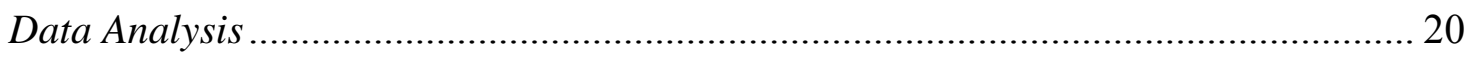

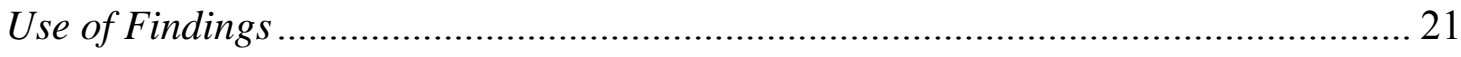

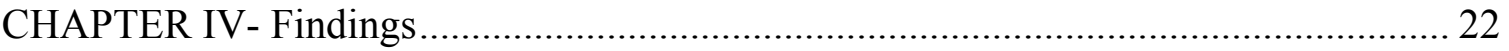

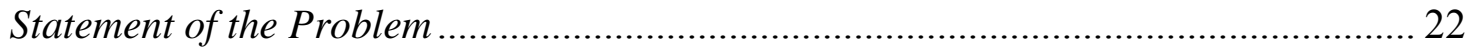

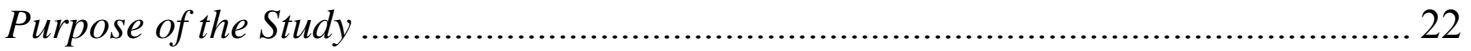

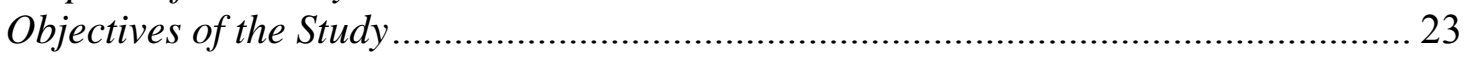

Demographic Characteristics of Respondents............................................................ 23

Attitudes of Respondents toward Calf Pool Organization ............................................ 27

Level of Participation in West Virginia Calf Pools ......................................................33

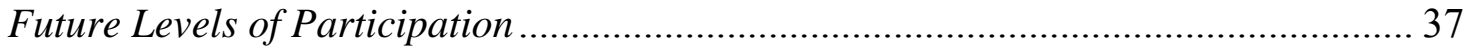

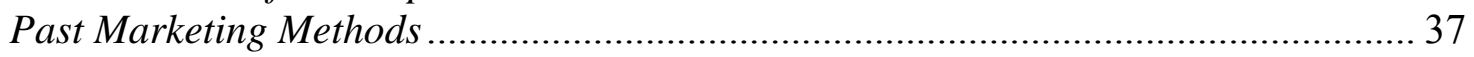

Why Did You not Participate in 2005 or 2006 ....................................................... 38

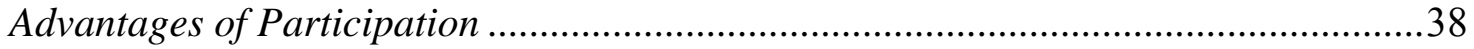

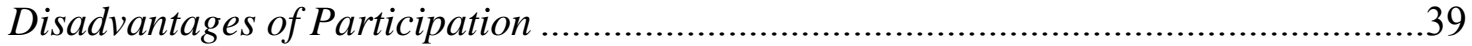

Suggested Improvements to Calf Pools......................................................................40 
CHAPTER V- Summary, Conclusions and Recommendations ................................. 41

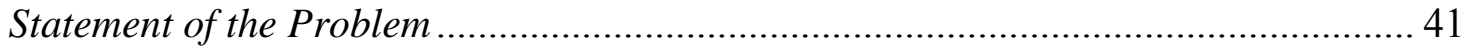

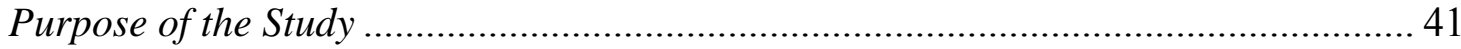

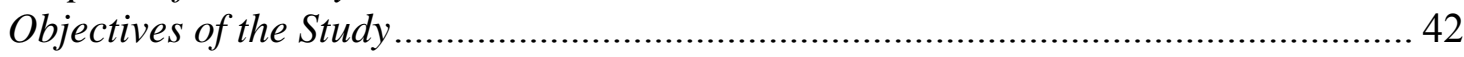

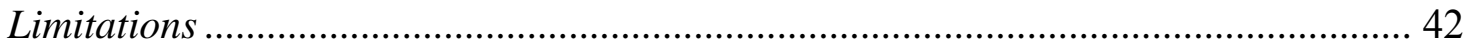

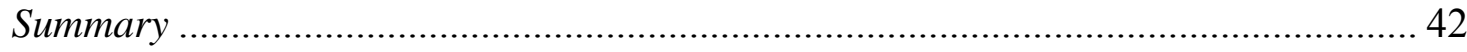

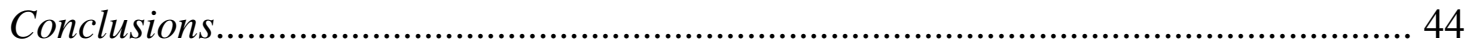

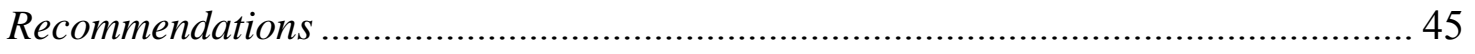

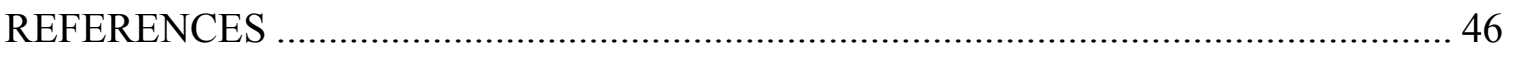

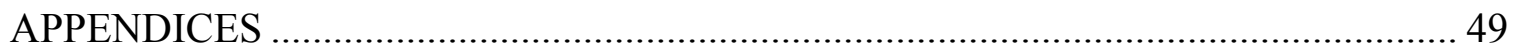

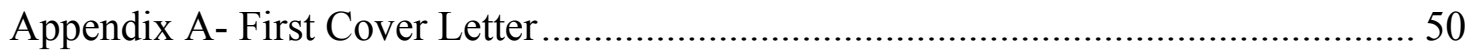

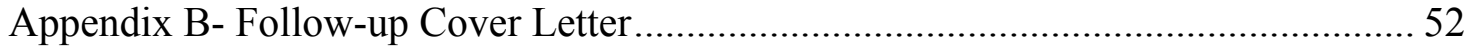

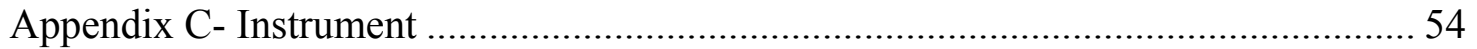

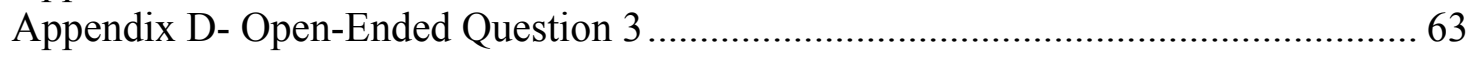

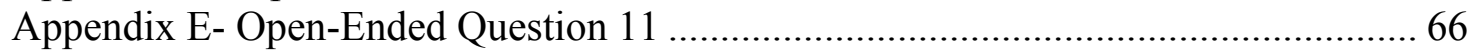

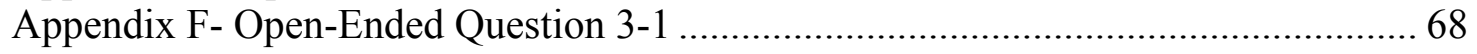

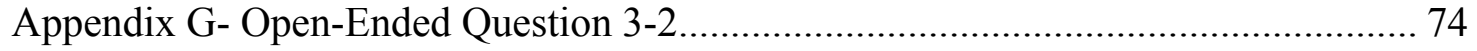

Appendix H- Open-Ended Question 3-3 ............................................................... 84

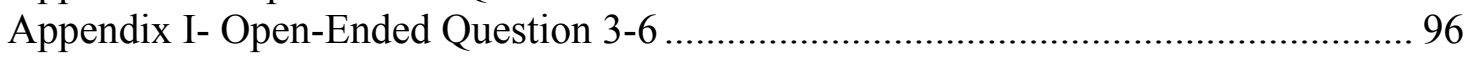

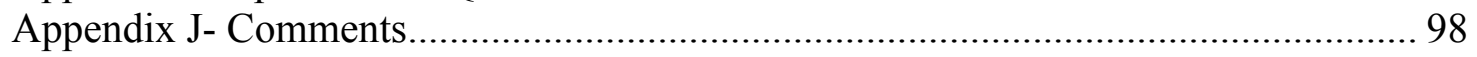

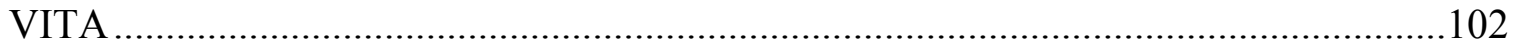




\section{LIST OF TABLES}

Table

$1 \quad$ Gender and Age of WV Calf Pool Participants .................................................. 24

$2 \quad$ Number of Years Respondents Participated in WV Calf Pools ........................... 25

$3 \quad$ Role and Utilization of Outside Labor ............................................................... 25

$4 \quad$ Calf Pool Participants by WV Calf Pool Location .............................................. 26

$5 \quad$ Attitudes of Respondents toward WV Calf Pool Organizations .......................... 29

6 Respondents who Participated in West Virginia Calf Pools in 2005 or 2006

and Respondents who Participated Prior to 2005 but not 2005 or 2006 ...............34

$7 \quad$ Respondents' Level of Participation in WV Calf Pools ...................................... 36

8 Participants Who Plan to Increase Number of Calves in the Next Five Years..... 37

$9 \quad$ Marketing Methods Used Prior to Joining WV Calf Pools ................................ 38 


\section{CHAPTER I}

Introduction

Farming can be defined as an occupation requiring independence and selfsufficiency to produce agricultural products for sale to the public (Rymer, 2006). Rarely is there an industry having thousands of small branch offices being managed with few consistencies between them and each branch competes for higher prices than their counterparts. Farming is also one of the few industries that fully produces a commodity and only then begins to search for a buyer. This marketing strategy puts farmers in the position to "take" the price, not "make" the price (Avent, Ward \& Lalman, 2002). Sometimes this marketing strategy even results in the farmer losing money. When this occurs in animal agriculture, producers often become discouraged and strive for a better market option the next year (Hendrickson \& Lehmkuhler, 2002).

Marketing strategies have certainly evolved over the years. Barter, or trade, began right along with agriculture. Before agriculture was developed, the survival method was following food sources (herds of animals). Groups eventually came to the realization that they could grow their food in one area, no longer having to travel endlessly, and began

planting seeds. The need to secure their food was met. According to Maslow's Hierarchy of Needs, when basic needs are met, people can occupy their time doing things they like to do, or specializing (Huitt, 2004).

To effectively distribute food, those who had a certain commodity traded their surplus for things they didn't have. Trade and bartering were eventually superseded with money for simplicity's sake. One no longer had to find someone who needed your extra commodities; you could trade currency for increased convenience (Bartels, 1976). 
The object of trade, or purchasing, is to get what you need at the lowest sacrifice to you (Townes, 2006). We are sometimes willing to pay a little more for a high quality product, or something that is specially packaged to save us extra effort (Reilly, 1989). Noecker (2003) noted that the four Ps of marketing include product, price, promotion and packaging. Each beef producer, managing his/her own branch of the farming industry must concern himself/herself with the four P's that his/her consumer (the feedlot owner) would want.

Feedlot owners typically begin buying calves in September of each year. They want 5-8 month old calves (product), as cheap as they can get them (price), and they want these from a farmer with a good reputation (promotion). Finally, they want several animals of a consistent size and quality (packaging) (USDA, 1982).

Marketing is the key aspect in selling. Marketing is a detailed industry with a rich history. The American Marketing Association (2006) suggests that marketing is "an organizational function and a set of processes for creating, communicating and delivering value to customers and for managing customer relationships in ways that benefit the organization and its stakeholders" (p. 7). One of the most recent marketing changes in the beef cattle industry has been calf pool organizations.

A calf pool is defined as a group of small producers "pooling" calves and resources to create a large group of uniform, high-quality calves. Calf pools are organizations, usually county-based, that include farmers who cooperate with other farmers in creating a more profitable market for their calves. The organization's main purpose is to draw from a larger collection of calves to sort into groups of a similar size to make them more marketable (Osborne, 1998). 
A calf pool is a group of beef producers having something in common, be it cattle breed or simply geography, that can market calves in categories sorted by weight and color to form a consistent truckload. A truckload desired by feedlot owners is actually comprised of 50,000 pounds of feeder cattle for finish. The purpose of a calf pool is to create a consistent, high-quality product that a feedlot owner will desire and be willing to pay for in quantities great enough to make it worthwhile for everyone (Osborne, 1998). For example, if a feedlot owner in Kansas wanted 50,000 pounds of steers, the calf pool would select and ship approximately 80 steers all weighing around 625 pounds to the buyer. In return for the buyer not having to go to the stockyard or bid online for the steers, he is usually willing to pay a slightly higher-than-market price to the producer.

Calf pools uphold a strict set of guidelines and management requirements to ensure quality calves. Among these are recordkeeping, a tightened calving season, and a series of vaccinations to be given on a very timely basis. The injections are one of the most important steps in the calf pool process.

To encourage proper injection of calves, calf pools are requiring their participants to be members of the Beef Quality Assurance (BQA) program. Beef Quality Assurance is a program which educates farmers on the production of safe, quality beef (Mid-Atlantic Beef Quality Assurance, 2006). One of the major issues is proper methods of injecting animals to avoid contamination and damage of valuable meat cuts. Damage can be caused by needles injecting chemicals into the muscle, thus decreasing the value of the final cuts of meat. Prior to the calf pool, farmers would sell their calves to feedlot owners who in turn would sell them to animal processing units, or slaughterhouses. The slaughterhouse would be the unlucky one to find the damage that medications and 
injections cause to the cuts of meat. Prior to BQA training, the most popular place to inject was intramuscularly on the hip (the round/loin area). Medications could discolor the meat or leave chemical residues and render it unusable. Because of BQA training, most injections are now given in the neck, subcutaneously (just under the skin) and avoid damage to higher priced cuts of meat. Being BQA certified helps to increase a producer's calf prices.

The addition of BQA certification clearly assists in justifying the higher prices of calves marketed through the calf pools. Even more recently, two additional levels of value-added have been introduced into the calf pool organizations.

The Silver level includes calves that have had a series of injections or vaccinations about three weeks prior to being collected and graded for shipping. This series of shots helps to insure the buyer from shipping fever and other illnesses that the calves may pick up due to stress of being moved and separated from their mothers. These calves may or may not have been creep-fed. Creep feeding is a common method of introducing a calf to eating grain earlier than 5 months of age. Creep feeding is allowing a calf access to grain while it is still pasturing with its mother. Grain feeding can have a positive effect from the time a calf is five months old (Rasby, 2006). Creep feeding is accomplished by providing enclosed feeders so that a calf can gain access to the grain, but the larger mothers cannot. This is the most efficient way of adding weight to the growing calf (Osborne, 1998).

The Gold level is a more labor-intensive program, and refers to calves that have been weaned, or separated from their mothers for 30 days or more. During this time, they have been given a second round of vaccinations, or boosters. The first vaccinations were 
the series required by the Silver level, and the calf has been introduced to grain. These calves may or may not have been creep fed, but will be accustomed to eating grain by the time they are graded and shipped. The three-week separation period gives the calves the opportunity to adjust to being without their dams (mothers) and being clustered with other calves. There has been evidence that the Gold level calves bring more money than the Silver, but how much more is not yet clear.

The calf pool organization employs many management strategies. West Virginia University's Cooperative Extension Service Farm Specialist Tom McConnell says, “a feedlot owner desires a calf that comes off the truck and puts his head in a feed bunk." This behavior denotes that the calf has not been stressed and it will immediately begin eating the grain needed to gain weight. The feedlot owner's purpose is to put another 400-600 pounds on the animal and market to the slaughterhouse. The more the calf eats, the sooner the feedlot owner's goal is reached, and the happier he is with that producer's calves.

Besides helping the beef producer receive higher prices for his product, the calf pool organization promotes increased management of a farmer's herd. To consign animals to the pool, the producer must keep such records as birth date, dam (mother), and dates of shots or treatments. If a farmer is going to keep track of his/her calves, he/she might take the extra step to also keep records on his/her mother cows which leads to overall organization and good management (Born, 2001).

The reasoning behind the calf pool organizations is easy to understand when dissected. A calf pool could have 40 or more producers region-wide, each owning a small herd of feeder calves of varying weights. If each herd was taken to market individually, 
chances are the calves would not be well-matched, resulting in an average price. In addition, the buyers would probably never know if the calves had been vaccinated or creep fed. By allying the farmers and giving them a common goal, a calf pool would essentially create an entire community of farmers who are now in the position to market their animals on a higher level and demand an increased price for sets of consistent animals (Holt, Lord \& Simpson, 2006).

\section{Statement of the Problem}

Over 250 farmers participate in West Virginia calf pools. In order to get more West Virginia farmers involved in the cooperative style of marketing, promoters must clearly convey the benefits and sacrifices of participation in the West Virginia calf pool program. However, no study has been conducted to examine the satisfaction of the farmers or their thoughts for the improvement of the program.

While recently attempting to create a calf pool in an area that was not familiar with the program, there were many questions raised by the beef cattle producers. Some of the most common questions included:

Do farmers involved in existing calf pools find it helpful?

Are they making more money?

Do they feel the extra work is worth the extra profit?

No one could answer those questions without consulting several producers and asking their opinions. Other counties starting calf pools appear to be having the same concerns and without the factual information those questions will remain unanswered. 


\section{Purpose of the Study}

The purpose of the study was to determine the perceptions of calf pool participants toward the West Virginia calf pool organization. Information obtained from this study will be used to document calf pool participants' perceptions toward the organization.

\section{Objectives of the Study}

The primary objective of the study was to determine the perceptions which calf pool participants possess toward the West Virginia calf pool organization. The specific objectives were:

1. To determine the number of years beef producers have participated in the calf pool.

2. To determine the types and numbers of animals marketed via the calf pool.

3. To determine what percentage of animals producers were marketing via the calf pool.

4. To determine whether producers desired to market more animals via the calf pool.

5. To determine the level of satisfaction of producers who participate in the calf pool.

6. To determine the benefits from participation in the calf pool.

7. To determine how the calf pool organization might be improved. 


\section{Limitations to the Study}

The study is being limited to only beef producers involved with the calf pool organizations in West Virginia from 2000-2005. These producers are representative of calf pool producer participants in the state of West Virginia. 


\section{CHAPTER II}

\section{Review of Literature}

\section{Aspects of Marketing}

The key aspect to selling a product is marketing. Marketing not only includes advertising (commercials, fliers, and big sales), but the entire process: from deciding which product to create, until the product meets its final destination. If you read a number of marketing texts they will discuss the universal 4 Ps of selling. These are presenting the "right PRODUCT, at the right PRICE, in the right PLACE, with the right PROMOTION!" (Noecker, 2003, p. 4).

For many years, America's farmers have been marketing in one way or another. Decades ago, the social norm was that everyone had their own cow for milk and to raise calves to butcher. As cities grew and more people moved into them, the people who decided to stay on the farms were pressured to produce more than their family needed in order to supply the people who chose to live in the cities where they could not grow their own food. In 1900, each American farmer produced enough food to feed 7 other people; today that farmer is responsible for feeding 144 other people (NASS, 2007).

\section{Small Farming and Value-Adding}

The small farmer's difficulty is that he or she does not produce the volume level to demand a price. The situation becomes many small producers approaching conditions economists call pure competition, indicating it's each man/woman for his/her own. The individual here is a "price taker", not a "price maker" because he/she is one of many small farmers, all vying for the same market (USDA, 1982). Since most of these farmers can't compete in the high-volume commodity markets, they have to concentrate on quality, not quantity to sell their product (Born, 2001). 
An element of quality that has come to the surface in recent years is "valueadding." Reilly (1989) describes value-added as "how the manufacturer or distributor changes, enhances, or improves their basic product to increase its value to the buyer" ( $p$. 78). Reilly (1989) also says that the value-added salesman has two objectives. First, he wants to satisfy the buyer's needs. Second, he wants to do this in a way that is profitable for his organization. The salesperson discovers what is valuable to the buyer and then seeks ways to increase the value of his offering (Reilly, 1989).

Some "rules" of value-added selling according to Reilly (1989) are:

- Customer satisfaction is a function of customers' expectation. If you promise a lot and deliver more, you have satisfied customers who will likely pay more to remain a client of your company.

- No product is overpriced unless it's under-desired. If you get a price objection, it's generally because you haven't convinced the buyer sufficiently of the value you're offering. (p. 90)

Coordination of economic activities from producers to consumers is important. If what is produced is not consistent with what is being demanded by consumers, valuable resources are not used in the best way (USDA, 1982).

Beef Industry - Buying and Selling

In the beef industry, producers can add value to their calves by ensuring that they are healthy and of a good bloodline. Holt, Lord and Simpson (2006) state that feedlot operators try to buy calves that will gain predictably in the feedlot. Buyers will frequently pay a premium price for cattle that are of uniform size and weight. Uniformity begins with the cow herd and the type of bull(s) used. Cows should be of similar breed type and 
frame size to ensure similarly sized calves. Bulls should also be of the same breed if more than one bull is used during the breeding season; there can be a price premium for calves with the same color patterns.

Markets are topped by calves that are uniform and grouped into truckload lots (48,000 to 50,000 pounds) of steers or heifers. These large, uniform lots can and do attract competitive bids from the buyers in the market and hence, sell well. However, most owners of small herds cannot assemble truckload lots and so must look for other ways of selling their calves (Holt, et al., 2006).

Trying to market to feedlots is where the small farmer runs into trouble. Not many small producers can supply 50,000 pounds of calves, even if every one of the producer's own calves is consistent with each other. A simple solution for the small producer is to collaborate with other owners of small herds with similar breeding. This collaboration makes it easier for producers to assemble loads of similar calves, thereby improving price per pound.

\section{West Virginia Calf Pool Organization}

A calf pool is defined as a group of small producers "pooling" calves and resources to create a large group of uniform, high-quality calves. Calf pools are organizations, usually county-based, that include farmers who cooperate with other farmers in creating a more profitable market for their calves. The organization's main purpose is to draw from a larger collection of calves to sort into groups of a similar size to make them more marketable.

Extensive records are kept on the group of calves being sold through the calf pool. Sire and dam information is important to the bloodlines, and helps the farmer to recall 
which dams produce the best and fastest growing calves. Birth date information is important for many reasons, one of which is the standard concerning Bovine Spongiform Encephalopathy stating that animals over 30 months of age are not to be exported. Japan is currently not accepting any beef animal over 20 months of age (Cattle Network, 2006). Injection records are kept to provide proof to the buyer that the vaccinations were administered and on what date.

Management records are kept by some farmers anyway and are described as a good practice by Born (2001). He adds,

Trying to manage and grow an enterprise without good records is like trying to find an address in a strange city without a map. Without records, you are limited to making educated guesses about the progress of your business, whether or not you are meeting your goals and the possible reasons why or why not. (p. 3)

In following the value-added approach, the calves are vaccinated with a series of injections to ward off illnesses common to the weaning and shipping stages. While vaccinations are definitely a benefit, how they are administered is not always ideal. Keeping this in mind, the calf pool organizations began to require all members of the calf pools to also become members of the Beef Quality Assurance program.

The Beef Quality Assurance (BQA) program was made public in 1982 and its purpose is to "strengthen consumer confidence in beef by focusing the industry's attention on the strategies which promote beef quality and safety, through the use of science, research, and educational initiatives" (p. 2). The program requires farmers to learn by both hands-on and a workbook approach how to give injections, keep records 
pertaining to medications, and ensure the carcass quality of the animal he or she is marketing (Pennsylvania Beef Quality Assurance, 2006). Recertification is required every two years to guarantee that each producer receives new information. In turn, this avoids mark-downs on the slaughterhouse level due to damage and discoloration to the actual carcass.

In addition to encouraging a farmer to keep records and to take the best possible care of his calves, the calf pool organization provides a place for a farmer to market his calves. In the past, it was popular for a farmer to market his/her calves via the stockyard. Prices often varied depending upon how many total calves had been brought to sell that day, and how many buyers were in attendance. Another method of marketing was to hold a televised auction, broadcasting the lot of calves being sold and allowing buyers to bid on the telephone or online. Television marketing broadened the market, as geography was no longer an issue. However, the technology was sometimes prohibitive, and delivery was sometimes an issue. It was possible to put together a truckload and sell directly to a feedlot owner, but again, the small farmer ran into difficulty due to lack of quantity and lack of leverage in the market. Many producers still find themselves at a bargaining disadvantage as they negotiate with buyers. For one thing, producers typically have fewer sales outlets than buyers have sources of supply. Direct purchasing of agricultural commodities, in which terms of trade are individually negotiated, is much more common these days (USDA, 1982).

The calf pool organization in West Virginia has begun holding Quality Assurance (QA) sales. The QA sales use a two-tier health program. Calves in the Gold Program undergo a complete pre-vaccination regime 14 to 21 days before weaning. The calves get 
a booster vaccination for the respiratory complex and are weaned at least 30 days before delivery.

\section{Tiers within WV Calf Pools}

Some producer pools have adopted the Gold Program for the convenience of being able to gather and assemble calves from a number of producers or from a larger market area. The most distinct advantage of the Gold Program is the success the buyers have had with the calves from an animal health and performance perspective.

The Silver Program is limited to the pre-vaccination component of the Gold Program and administration is required 14 to 21 days before delivery. The prevaccination health programs for the Silver and Gold tiers are identical, allowing buyers to choose from both tiers and co-mingle them in the lots. Because all calves have been managed the same, the booster programs administered at the feedlot will be more compatible. The expense of the vaccination program is minimal, usually $\$ 6$ to $\$ 7.50$ per head (Osborne, 1998). The difference between the Silver and Gold programs, of course, would be the added expense of weaning. The expense is not only monetary, it requires time to separate calves, tend to them every day, haul water in some cases, and the second round of injections. The question is whether the added investment is worth the return. Osborne (1998) thinks that it is, saying,

A 12-year summary of receipts from the Morgantown calf pool has shown a $\$ 77.00$ per head advantage over the state graded feeder calf price. It is likely that most of the calves would have brought more than the average price without participating since many of the calves would have been above average anyway. However, when the group marketed its first calves 
there was very little difference from the average in price and pounds of calves marketed. With some established goals and objectives, the uniformity of the cattle improved over time with respect to conformation and performance. The average weight marketed is now nearly 100 pounds above the state average, and producers still realize a price advantage above the state average of the graded sales. (p.8)

On top of the increase in price, the calf pool organization provides benefits in other ways. Osborne (1998) illustrates,

Producers participating in marketing pools are beginning to realize savings in other areas, such as bulk orders of supplies, feed, vaccines, transportation, and even a sharing of bulls. The feeder calf marketing pools allow small producers to function with the advantages of the large producer. (p.8)

Producers will take more responsibility for the commodity they market by being more concerned with what they put into the product, rather than just the return. Thinking about and acting on these ideas might not guarantee the top sale price, but they could go a long way toward making sure your calves sell for all they're worth (Noecker, 2003). 


\section{CHAPTER III}

Methodology

\section{Statement of the Problem}

Over 250 farmers participate in West Virginia calf pools. In order to get more West Virginia farmers involved in the cooperative style of marketing, promoters must

clearly convey the benefits and sacrifices of participation in the West Virginia calf pool program. However, no study has been conducted to examine the satisfaction of the farmers or their thoughts for the improvement of the program.

While recently attempting to create a calf pool in an area that was not familiar with the program, there were many questions raised by the beef cattle producers. Some of the most common questions included:

Do farmers involved in existing calf pools find it helpful?

Are they making more money?

Do they feel the extra work is worth the extra profit?

No one could answer those questions without consulting several producers and asking their opinions. Other counties starting calf pools appear to be having the same concerns and without the factual information those questions will remain unanswered.

\section{Purpose of the Study}

The purpose of the study was to determine the perceptions of calf pool participants toward the West Virginia calf pool organization. Information obtained from this study will be used to document calf pool participants' perceptions toward the organization. 


\section{Objectives of the Study}

The primary objective of the study was to determine the perceptions which calf pool participants possess toward the West Virginia calf pool organization.

The specific objectives were:

1. To determine the number of years beef producers have participated in the calf pool.

2. To determine the types and numbers of animals marketed via the calf pool.

3. To determine what percentage of animals producers were marketing via the calf pool.

4. To determine whether producers desired to market more animals via the calf pool.

5. To determine the level of satisfaction of producers who participate in the calf pool.

6. To determine the benefits from participation in the calf pool.

7. To determine how the calf pool organization might be improved.

\section{Limitations to the Study}

The study is being limited to only beef producers involved with the calf pool organizations in West Virginia from 2000-2005. These producers are representative of calf pool producer participants in the state of West Virginia.

\section{Research Design}

A descriptive research design was chosen for the study. According to Ary, Jacobs, Razavieh and Sorenson (2006), "descriptive research allows for the researcher to summarize the characteristics of different groups or to measure their attitudes and 
opinions toward some issue" (p. 31). Descriptive research allows for a wider scope of information to be collected from a larger population, deals with real situations and allows for more specific problems to be identified. The disadvantages of using descriptive research is that the responses tend to be more superficial, it is labor-intensive, lacks external validity and it is difficult to obtain valid data due to measurement error. A questionnaire was used to collect information on farmers' attitudes toward the calf pool organization in the state of West Virginia.

\section{Population}

The target population was limited to participants of the calf pools in West Virginia. The list of participating farmers was obtained from the calf pool organization through West Virginia University. The names on the list were matched with the list of Beef Quality Assurance participants since to participate in the calf pool you must be BQA certified, to form a list of addresses. A total of 258 farmers were included in the accessible population. Selecting every farmer controlled sampling error. The list was reviewed and scanned for duplicate names to control selection error.

\section{Instrumentation}

The instrument used for this study was a three-part mail questionnaire. The questionnaire was designed specifically for this study in order to determine West Virginia calf pool participants' attitudes toward the calf pool organization. Following Dillman's suggestions, Part I consisted of questions to gain insight to the production level and past marketing experiences of the farmer. Part II consisted of twelve Likert scaled attitudinal items relating to the calf pool organization in West Virginia. Part III of the instrument requested demographic information about the population. The instrument was developed 
keeping in mind the known marketing avenues that West Virginia beef producers commonly use, and how calf pools differ from those.

The instrument was reviewed by a panel of experts at West Virginia University to establish its content and face validity. The panel of experts consisted of teacher educators in Agricultural and Extension Education. Each individual on the panel had extensive teaching and/or Extension field experience. The panel of experts concluded that the instrument had content and face validity.

The reliability of the instrument was determined using the data set from all respondents. The equal-length Spearman-Brown statistic (Pearson $r=.99)$ was used to establish the instrument's reliability. The instrument was determined to have exemplary reliability. (Robinson, Shaver, \& Wrightsman, 1991).

\section{Data Collection Procedures}

The questionnaire (see Appendix C) and cover letter (see Appendix A) were mailed to each individual in the target population. The cover letter explained the purpose of the study, gave directions for completing and returning the questionnaire, and provided an assurance of confidentiality. The letter was signed by the researcher and faculty advisor. The self-addressed return envelopes were coded for the purpose of identifying non-respondents.

Early and late respondents were recorded in an Excel spreadsheet during the data collection procedure. To ensure confidentially, no names were used on the instrument and only numbers were used to identify respondents. Two weeks after the first mailing deadline, non-respondents were mailed a second, follow-up letter (see Appendix B) that contained the same information as the first cover letter. An additional instrument and 
return envelope were enclosed in the mailing. The second cover letter contained the same information as the first, but included that the first mailing should have been received by the individual and that their response was needed for the study.

\section{Data Analysis}

Returned questionnaires were visually verified with each respondent's identification number and entered into an Excel spreadsheet. The data were transferred to the computer version of the Statistical Package for the Social Services (SPSS). The level of significance was set $a$ priori at $\leq .05$ for all statistical tests. Data analysis procedures included frequencies, percentages, and means to describe the population.

Non-response error was assessed by comparing early respondents to late respondents because "non-respondents are similar to late respondents" (Ary et al., 2006, p. 439). By categorizing respondents into early and late groups and comparing their responses for any significant relationships will determine if non-response error exists. According to Ary et al., (2006) if no significant difference appears between early and late respondents, then the respondents could be generalized to the entire population. To make certain that the findings are representative of the opinions of the entire population, nonresponse error must be avoided in the study.

The population for the study consisted of 258 calf pool participants. A $t$ test was conducted to determine if differences existed between early and late respondents on twelve Likert scaled items (opinions on each calf pool issue). The results indicate that there were significant differences between mean scores of early and late respondents on twelve Likert scaled items (opinions on each calf pool issue). The results indicate that 
there were significant differences between early and late respondents. Therefore, the results could not be generalized to the entire population.

\section{Use of Findings}

Based on the findings of this study, interested individuals will be able to determine participating farmers' attitudes toward the calf pool organization in West Virginia. Findings from this study will be available through the West Virginia University Library to farmers in West Virginia and other interested parties. 


\section{CHAPTER IV}

\section{Findings}

\section{Statement of the Problem}

Over 250 farmers participate in West Virginia calf pools. In order to get more West Virginia farmers involved in the cooperative style of marketing, promoters must

clearly convey the benefits and sacrifices of participation in the West Virginia calf pool program. However, no study has been conducted to examine the satisfaction of the farmers or their thoughts for the improvement of the program.

While recently attempting to create a calf pool in an area that was not familiar with the program, there were many questions raised by the beef cattle producers. Some of the most common questions included:

Do farmers involved in existing calf pools find it helpful?

Are they making more money?

Do they feel the extra work is worth the extra profit?

No one could answer those questions without consulting several producers and asking their opinions. Other counties starting calf pools appear to be having the same concerns and without the factual information those questions will remain unanswered.

\section{Purpose of the Study}

The purpose of the study was to determine the perceptions of calf pool participants toward the West Virginia calf pool organization. Information obtained from this study will be used to document calf pool participants' perceptions toward the organization. 


\section{Objectives of the Study}

The primary objective of the study was to determine the perceptions which calf pool participants possess toward the West Virginia calf pool organization.

The specific objectives were:

1. To determine the number of years beef producers have participated in the calf pool.

2. To determine the types and numbers of animals marketed via the calf pool.

3. To determine what percentage of animals producers were marketing via the calf pool.

4. To determine whether producers desired to market more animals via the calf pool.

5. To determine the level of satisfaction of producers who participate in the calf pool.

6. To determine the benefits from participation in the calf pool.

7. To determine how the calf pool organization might be improved.

\section{Limitations to the Study}

The study is being limited to only beef producers involved with the calf pool organizations in West Virginia from 2000-2005. These producers are representative of calf pool producer participants in the state of West Virginia.

\section{Demographic Characteristics of Respondents}

Respondents were asked to complete five closed-ended questions and one openended question that related to the respondent's gender, age, number of cows to calve in 
spring of 2006, role in the farming operation, use of outside labor, and the location of their calf pool.

Of the respondents, 154 (89\%) were male and eight (4.6\%) were female. Eleven respondents $(6.4 \%)$ did not report gender. One $(0.6 \%)$ respondent was between 21 and 30 years of age. Thirteen (7.5\%) respondents stated that they were in the $31-40$ years category. Thirty-seven (21.4\%) producers marked the 41-50 years of age category. The 51-60 years of age category included 57 (32.9\%) individuals. Thirty-seven $(21.4 \%)$ individuals were between 61-70 years old and 17 (9.8\%) were over the age of 71 (see Table 1).

Table 1

Gender and Age of WV Calf Pool Participants

\begin{tabular}{lcc}
\hline & $f$ & $\%$ \\
\hline Gender & 154 & \\
Male & 8 & 89.0 \\
Female & 11 & 4.6 \\
Not Reported & & 6.4 \\
Age & 0 & 0.0 \\
under 21 years & 1 & 0.6 \\
$21-30$ years & 13 & 7.5 \\
$31-40$ years & 37 & 21.4 \\
$41-50$ years & 57 & 32.9 \\
$51-60$ years & 37 & 21.4 \\
$61-70$ years & 17 & 9.8 \\
Over 71 years & & \\
\hline
\end{tabular}


Beef producers were asked to report how many years they had participated in the calf pool. Reports ranged from one year to 30 years, with a mean of $6.53(S D=4.86)$.

Table 2

Number of Years Producers Participated in West Virginia Calf Pools

\begin{tabular}{ccccc}
\hline & Mean & $S D$ & Minimum & Maximum \\
\hline Years participated & 6.53 & 4.86 & 1 & 30 \\
\hline
\end{tabular}

Of the 173 respondents, $78(48.1 \%)$ reported that their role in the operation was full-time farmer, and had no other job outside the farm. Eighty-four (51.9\%) reported that they were part-time farmers. When asked if they utilized outside labor, 59 (36.9\%) replied that they did and 101 (63.1\%) answered that they did not use outside labor (see Table 3).

Table 3

Role and Utilization of Outside Labor by Calf Pool Participants

\begin{tabular}{lcc}
\hline & $f$ & $\%$ \\
\hline Role & 78 & \\
Full-time farmer & 84 & 58.1 \\
Part-time farmer & & 51.9 \\
Utilization of Outside Labor & 99 & 36.9 \\
Yes & 101 & 63.1 \\
No & & \\
\hline
\end{tabular}

Participants were asked to report the calf pool in which he/she participated. Twenty-seven (15.6\%) individuals participated in the Jackson-Mason calf pool, 23 $(13.3 \%)$ respondents belonged to the Pendleton-Hampshire pool, and $21(12.1 \%)$ 
individuals sold through the Morgantown calf pool. Eighteen (10.4\%) respondents reported participation in the Central calf pool and 13 (7.5\%) individuals answered that they sold through the Marshall-Ohio calf pool. Ten Nicholas-Fayette calf pool participants (5.8\%) answered the study. Nine (5.3\%) respondents reported participation in each the Monroe-Greenbrier and the Roane calf pools. Three pools had seven (4.0\%) respondents, including the Barbour, Tyler and Randolph-Tucker pools. Six (2.9\%) respondents reported "other" as their pool, and five (2.9\%) participants belonged to the Wirt pool (see Table 4).

Table 4 Pool Participants By West Virginia Calf Pool Location

\begin{tabular}{lcc}
\hline & $f$ & $\%$ \\
\hline Jackson-Mason & 27 & 15.6 \\
Pendleton-Hampshire & 23 & 13.3 \\
Morgantown & 21 & 12.1 \\
Central & 18 & 10.4 \\
Marshall-Ohio & 13 & 7.5 \\
Nicholas-Fayette & 10 & 5.8 \\
Monroe-Greenbrier & 9 & 5.3 \\
Roane & 9 & 5.3 \\
Barbour & 7 & 4.0 \\
Randolph-Tucker & 7 & 4.0 \\
Tyler & 7 & 4.0 \\
Other & 6 & 2.9 \\
Wirt & 5 & 2.9 \\
\hline
\end{tabular}


Respondents were asked how many heifers and cows they expected to calve in the spring of 2006. The responses ranged from zero to 325 animals, with a mean of 58.5 animals.

\section{Attitudes of Respondents toward Calf Pool Organization}

Using a six-point Likert scale, respondents were asked 12 questions concerning calf pool organization. The scale consisted of the following six levels of measurement: 1“strongly disagree" 2-“moderately disagree" 3-“slightly disagree" 4-“slightly agree" 5“moderately agree" and 6-“strongly agree." The responses were averaged and the following scale was used to interpret the results: "strongly disagree"- 1.00-1.50, “moderately disagree"- 1.51-2.50, "slightly disagree"- 2.51-3.50, "slightly agree"- 3.514.50, "moderately agree"- 4.51-5.50, and "strongly agree"- 5.51-6.00.

Participants of the study were asked to react to the following statement, "I incurred additional costs as a result of participating in the calf pool." Ninety-five participants (58.6\%) “strongly agreed." Forty-five individuals $(27.8 \%)$ "moderately agreed," and 17 respondents (10.5\%) "slightly agreed" with the statement. One respondent $(0.6 \%)$ "slightly disagreed" and four individuals $(2.5 \%)$ "moderately disagreed" that they had incurred additional costs due to participation in the calf pool. The Likert item had a mean score of 5.40, placing it in the "moderately agree" category (see Table 5).

Participants in the study were asked to react to the following statement, "I am satisfied with the operation of my calf pool." Sixty-two participants (38.3\%) "strongly agreed," 70 respondents $(43.2 \%)$ "moderately agreed," nine individuals (5.6\%) "slightly agreed," 10 participants (6.2\%) "slightly disagreed," six respondents (3.7\%) "moderately 
disagreed," and five participants (3.1\%) "strongly disagreed" with the statement. The mean score was 4.97, placing it in the "moderately agree" category (see Table 5).

Respondents were asked to react to the following statement, "Participation in the calf pool has encouraged me to be a better manager." Seventy respondents (43.2\%) "strongly agreed" with the statement, 55 participants (34\%) "moderately agreed," 25 respondents (15.4\%) "slightly agreed," and three participants (1.9\%) "slightly disagreed." Five respondents (3.1\%) "moderately disagreed" and four individuals (2.5\%) "strongly disagreed." The mean score for the statement was 5.05 , placing it in the "moderately agree" category (see Table 5).

Respondents were asked to react to the following statement, "I receive abovemarket prices by participating in the calf pool." Seventy-three participants (45.1\%) "strongly agreed" with the statement, 45 respondents (27.8\%) "moderately agreed," and $31(19.1 \%)$ "slightly agreed" with the statement. Eight respondents (4.9\%) "slightly disagreed," two individuals (1.2\%) "moderately disagreed," and three participants (1.9\%) "strongly disagreed" with the statement that they receive above-market prices through participation in the calf pool. The mean score for the item was 5.05, placing it in the “moderately agree" category (see Table 5).

Participants were asked to react to the following statement, "I will continue to participate in a calf pool." Seventy-nine participants (49.4\%) "strongly agreed," 55 respondents (34.4\%) "moderately agreed," and 16 individuals (10\%) "slightly agreed." Two (1.3\%) "moderately disagreed," and eight respondents (5\%) "strongly disagreed" that they would continue to participate in a calf pool. The mean score for the item 5.16, placing it in the "moderately agree" category (see Table 5). 
Table 5

Attitudes of Respondents toward West Virginia Calf Pool Organizations

\begin{tabular}{|c|c|c|c|c|c|c|c|c|c|c|c|c|c|}
\hline \multirow[t]{2}{*}{ Variables } & \multicolumn{2}{|c|}{$\begin{array}{l}\text { Strongly } \\
\text { Disagree }\end{array}$} & \multicolumn{2}{|c|}{$\begin{array}{l}\text { Moderately } \\
\text { Disagree }\end{array}$} & \multicolumn{2}{|c|}{$\begin{array}{l}\text { Slightly } \\
\text { Disagree }\end{array}$} & \multicolumn{2}{|c|}{ Slightly Agree } & \multicolumn{2}{|c|}{$\begin{array}{l}\text { Moderately } \\
\text { Agree }\end{array}$} & \multicolumn{2}{|c|}{ Strongly Agree } & \multirow[t]{2}{*}{$M$} \\
\hline & $f$ & $\%$ & $f$ & $\%$ & $f$ & $\%$ & $f$ & $\%$ & $f$ & $\%$ & $f$ & $\%$ & \\
\hline I incurred additional costs & 0 & .0 & 4 & 2.5 & 1 & .6 & 17 & 10.5 & 45 & 27.8 & 95 & 58.6 & 5.40 \\
\hline I am satisfied with pool & 5 & 3.1 & 6 & 3.7 & 10 & 6.2 & 9 & 5.6 & 70 & 43.2 & 62 & 38.3 & 4.97 \\
\hline $\begin{array}{l}\text { Pool encouraged me to be a } \\
\text { better manager }\end{array}$ & 4 & 2.5 & 5 & 3.1 & 3 & 1.9 & 25 & 15.4 & 55 & 34.0 & 70 & 43.2 & 5.05 \\
\hline I receive above-market prices & 3 & 1.9 & 2 & 1.2 & 8 & 4.9 & 31 & 19.1 & 45 & 27.8 & 73 & 45.1 & 5.05 \\
\hline $\begin{array}{l}\text { I will continue to participate } \\
\text { in a pool }\end{array}$ & 8 & 5.0 & 2 & 1.3 & 0 & .0 & 16 & 10.0 & 55 & 34.4 & 79 & 49.4 & 5.16 \\
\hline I keep better records & 6 & 3.7 & 5 & 3.1 & 11 & 6.8 & 23 & 14.2 & 38 & 23.5 & 79 & 48.8 & 4.97 \\
\hline Pool made me better manager & 5 & 3.1 & 6 & 3.7 & 3 & 1.9 & 32 & 19.8 & 61 & 37.7 & 55 & 34.0 & 4.87 \\
\hline $\begin{array}{l}\text { The benefits are worth the } \\
\text { expense }\end{array}$ & 7 & 4.3 & 3 & 1.9 & 9 & 5.6 & 33 & 20.4 & 46 & 28.4 & 64 & 39.5 & 4.85 \\
\hline $\begin{array}{l}\text { I implemented recordkeeping } \\
\text { system for pool calves }\end{array}$ & 8 & 5.0 & 3 & 1.9 & 14 & 8.8 & 38 & 23.8 & 41 & 25.6 & 56 & 35.0 & 4.68 \\
\hline
\end{tabular}


Table 5 (Continued)

Attitudes of Respondents toward West Virginia Calf Pool Organizations

\begin{tabular}{|c|c|c|c|c|c|c|c|c|c|c|c|c|c|}
\hline \multirow[t]{2}{*}{ Variables } & \multicolumn{2}{|c|}{$\begin{array}{l}\text { Strongly } \\
\text { Disagree }\end{array}$} & \multicolumn{2}{|c|}{$\begin{array}{l}\text { Moderately } \\
\text { Disagree }\end{array}$} & \multicolumn{2}{|c|}{$\begin{array}{l}\text { Slightly } \\
\text { Disagree }\end{array}$} & \multicolumn{2}{|c|}{ Slightly Agree } & \multicolumn{2}{|c|}{$\begin{array}{l}\text { Moderately } \\
\text { Agree }\end{array}$} & \multicolumn{2}{|c|}{ Strongly Agree } & \multirow[t]{2}{*}{$M$} \\
\hline & $f$ & $\%$ & $f$ & $\%$ & $f$ & $\%$ & $f$ & $\%$ & $f$ & $\%$ & $f$ & $\%$ & \\
\hline $\begin{array}{l}\text { I changed feeding rations to } \\
\text { increase growth }\end{array}$ & 11 & 6.8 & 4 & 2.5 & 11 & 6.8 & 44 & 27.2 & 43 & 26.5 & 49 & 30.2 & 4.55 \\
\hline I observe more for diseases & 10 & 6.2 & 4 & 2.5 & 13 & 8.0 & 55 & 34.0 & 38 & 23.5 & 42 & 25.9 & 4.44 \\
\hline $\begin{array}{l}\text { I spend more time in calving } \\
\text { season }\end{array}$ & 22 & 13.7 & 8 & 5.0 & 23 & 14.3 & 49 & 30.4 & 30 & 18.6 & 29 & 18.0 & 3.89 \\
\hline
\end{tabular}


Respondents were asked to react to the following statement, "As a result of the calf pool, I keep better records (birthdates, injections, etc.)." Seventy-nine respondents (48.8\%) "strongly agreed," 38 participants (23.5\%) “moderately agreed," and 23 individuals (14.2\%) "slightly agreed." Eleven individuals (6.8\%) "slightly disagreed," five respondents (3.1\%) "moderately disagreed," while six individuals (3.7\%) "strongly disagreed" that they keep better records on their calves as a result of the calf pool. The mean score for this item was 4.97, placing it in the "moderately agree" category (see Table 5).

Individuals were asked to react to the following statement, "As a result of the calf pool I have become a better manager of my operation.” Fifty-five respondents (34\%) "strongly agreed," 61 individuals (37.7\%) "moderately agreed," and 32 participants (19.8\%) "slightly agreed." Three individuals (1.9\%) "slightly disagreed," six participants (3.7\%) "moderately disagreed," and five respondents (3.1\%) "strongly disagreed" with the statement. The mean score for the statement was 4.87 , placing it in the "moderately agreed" category (see Table 5).

Respondents were asked to react to the following statement, "The benefits of participating in the calf pool are worth the expense." Sixty-four respondents (39.5\%) "strongly agreed," 46 participants (28.4\%) "moderately agreed," and 33 individuals (20.4\%) "slightly agreed" with the statement. Nine participants (5.6\%) "slightly disagreed," three individuals (1.9\%) "moderately disagreed," and seven participants (4.3\%) "strongly disagreed" that the benefits of participation in the calf pool are worth the expense. The mean score for the item is 4.85 , placing it in the "moderately agree" category (see Table 5). 
Participants were asked to react to the following statement, "I implemented a recordkeeping system to track animals to include in the calf pool." Fifty-six (35\%) of the respondents "strongly agreed," 41 participants (25.6\%) "moderately agreed," and 38 individuals (23.8\%) "slightly agreed" with the statement. Fourteen respondents (8.8\%) "slightly disagreed," three individuals (1.9\%) "moderately disagreed," and eight respondents (5\%) "strongly disagreed" that they implemented a recordkeeping system to track their calf pool calves. The mean score for the item was 4.68 , placing it in the “moderately agree" category (see Table 5).

Participants were asked to react to the following statement, "As a result of the calf pool, I have changed my feeding rations to increase growth of the animals." Forty-nine respondents (30.2\%) "strongly agreed," 43 individuals (26.5\%) "moderately agreed," and 44 participants (27.2\%) "slightly agreed." Eleven participants (6.8\%) "slightly disagreed," four individuals (2.5\%) "moderately disagreed," and 11 respondents (6.8\%) "strongly disagreed" that the calf pool influenced them to change feeding rations to increase growth. The Likert item mean score was 4.55 , placing it in the "moderately agree" category (see Table 5).

Respondents to the survey were asked to react to the following statement, "As a result of the calf pool, I observe my animals more closely for disease problems." Fortytwo respondents (25.9\%) "strongly agreed," 38 participants (23.5\%) "moderately agreed," and 55 individuals (34\%) "slightly agreed" with the statement. Thirteen individuals ( $8 \%$ ) "slightly disagreed," four respondents (2.5\%) "moderately agreed," and 10 respondents $(6.2 \%)$ "strongly disagreed" that they more closely observe their animals 
for disease problems. The mean score for the statement was 4.44 , placing it in the "slightly agreed" category (see Table 5).

Individuals were asked to react to the following statement, "As a result of the calf pool, I spend more time with my animals in calving season." Twenty-nine participants (18\%) "strongly agreed," 30 individuals (18.6\%) "moderately agreed," and 49 respondents (30.4\%) "slightly agreed" with the statement. Twenty-three respondents (14.3\%) "slightly disagreed," eight individuals (5.0\%) "moderately disagreed," and 22 participants (13.7\%) "strongly disagreed" that due to the calf pool they spend more time with their animals in calving season. The mean score for the item was 3.89, placing it in the "slightly agreed" category (see Table 5).

\section{Level of Participation in West Virginia Calf Pools}

Calf pool participants were asked if they had participated in a calf pool in either 2005 or 2006. One hundred forty-five respondents (83.8\%) replied that they had participated in either 2005 or 2006 . Twenty-one individuals (12.1\%) replied that they had not participated, and seven respondents (4.0\%) did not respond to the question (see Table $6)$.

If an individual reported that they hadn't participated in 2005 or 2006, they were asked if they had participated in a calf pool prior to 2005 . Fourteen respondents $(70.0 \%)$ indicated that they had participated prior to 2005 and six individuals (30.0\%) reported that they had not (see Table 6). 
Table 6

Respondents Who Participated in West Virginia Calf Pool in 2005 and/or 2006 and Respondents Who Participated in West Virginia Calf Pools prior to 2005 but not in 2005 or 2006

$f$

Participated in 2005 and/or 2006

Did not respond

Yes

No
7

145

21
$\%$

$$
4.0
$$

83.8

12.1

Participated prior to 2005 but not in 2005 or 2006

Yes

No
14

6
70.0

30.0

The questionnaire included a series of questions concerning the participant's membership in a calf pool. Respondents were asked to report how many calves were born on their farm in the years 2005 and 2006. Steers born on the farm in 2005 ranged from zero to 160 with a mean of $28.03(S D=27.83)$. In 2006 steers born on the farm ranged from zero to 160 , with a mean of $27.93(S D=28.72)$.

Respondents were asked to report how many steer calves they had purchased for resale through the calf pool in the years of 2005 and 2006. In 2005, participants reported purchasing between zero and 128 steers for resale through the calf pool with a mean of $1.77(S D=12.44)$. Steers bought in 2006 for resale through the calf pool ranged from zero to 128 with an average of $1.66(S D=12.46)$ 
Participants were asked how many steers they sold through the calf pool in 2005 and 2006. Steers in 2005 ranged from zero to 235 with a mean of $23.00(S D=29.29)$, and steers in 2006 ranged from zero to 232 with a mean of $23.07(S D=29.44)$.

Participants were asked how many steers they had contributed to the calf pool the first year they participated. Responses ranged from zero to 100 with a mean of 17.01 $(S D=14.37)$.

Participants were asked how many heifer calves were born on their farm in the years 2005 and 2006. Heifers born on the farm in 2005 ranged from zero to 150 with a mean of $25.94(S D=26.44)$. Heifers born on the farm in 2006 ranged from zero to 172 with a mean of $27.19(S D=28.78)$ (see Table 7).

Participants were asked to report how many heifers they had purchased in the years 2005 and 2006 for resale through the calf pool. Heifers purchased in 2005 for resale through the calf pool ranged from zero to 88 with a mean of $1.79(S D=9.71)$ and heifers purchased in 2006 for resale through the calf pool ranged from zero to 53 with a mean of $1.01(S D=6.28)$ (see Table 7).

Respondents were asked how many heifers they had consigned through the pool in the years 2005 and 2006. The number of heifers each participant sold through the pool in 2005 ranged from zero to 125 with a mean of $14.11(S D=17.83)$. Heifers sold through the pool in 2006 ranged from zero to 125 with a mean of $14.45(S D=16.94)$ (see Table 7).

Participants were asked how many heifers they had contributed their first year participating in the calf pool. Responses ranged from zero to 60 with a mean of 11.56 $(S D=11.02)$ (see Table 7). 
Respondents were asked "What is the maximum number of calves you could contribute to a calf pool given your current physical resources (land, labor and water)?" Responses ranged from one to 300 calves with a mean of $59.10(S D=53.08)$ (see Table 7).

Table 7

Respondents Level of Participation in West Virginia Calf Pools

\begin{tabular}{|c|c|c|c|c|}
\hline & $M$ & $S D$ & Min & $\operatorname{Max}$ \\
\hline \multicolumn{5}{|l|}{ Steers } \\
\hline Steers born on farm '05 & 28.03 & 27.83 & 0 & 160 \\
\hline Steers born on farm '06 & 27.93 & 28.72 & 0 & 160 \\
\hline Steers bought ' 05 & 1.77 & 12.44 & 0 & 128 \\
\hline Steers bought '06 & 1.66 & 12.46 & 0 & 128 \\
\hline Steers in pool '05 & 23.00 & 29.29 & 0 & 235 \\
\hline Steers in pool '06 & 23.07 & 29.44 & 0 & 232 \\
\hline Steers your first year in pool & 17.01 & 14.37 & 0 & 100 \\
\hline \multicolumn{5}{|l|}{ Heifers } \\
\hline Heifers born on farm '05 & 25.94 & 26.44 & 0 & 150 \\
\hline Heifers born on farm '06 & 27.19 & 28.78 & 0 & 172 \\
\hline Heifers bought '05 & 1.79 & 9.71 & 0 & 88 \\
\hline Heifers bought '06 & 1.01 & 6.28 & 0 & 53 \\
\hline Heifers in pool '05 & 14.11 & 17.83 & 0 & 125 \\
\hline Heifers in pool '06 & 14.45 & 16.94 & 0 & 125 \\
\hline Heifers your first year in pool & 11.56 & 11.02 & 0 & 60 \\
\hline $\begin{array}{l}\text { Maximum number of calves } \\
\text { farmer could contribute with } \\
\text { current resources }\end{array}$ & 59.10 & 53.08 & 1 & 300 \\
\hline
\end{tabular}




\section{Future Levels of Participation}

Participants were asked to respond to the question, "Do you plan to increase the number of calves you contribute to calf pools in the next five years?" Eighty-one $(54.7 \%)$ responded that they do plan to increase the number of calves and $67(45.3 \%)$ responded that they do not plan to increase the number of calves within the next five years (see Table 8).

Table 8

Participants Who Plan to Increase Number of Calves in the Next Five Years

\begin{tabular}{lcc}
\hline & $f$ & $\%$ \\
\hline Yes & 81 & 54.7 \\
No & 67 & 45.3 \\
\hline
\end{tabular}

\section{Past Marketing Methods}

Respondents were asked, "Before you participated in the calf pool, how did you market your animals? Check all that apply." One hundred thirty-five respondents $(78.0 \%)$ sold to stockyards, 38 individuals $(22.0 \%)$ sold to brokers, 38 respondents $(22.0 \%)$ sold freezer beef, and 11 individuals (6.4\%) sold their animals by the truckload. Five participants $(2.9 \%)$ had used videomarketing and one participant $(0.6 \%)$ had sold online. Thirty-four participants (19.7\%) marked "other," and listed the alternative method. Some of these were private treaty, retained ownership and selling directly to feedlots (see Table 9). 
Table 9

Marketing Methods Used Prior to Joining West Virginia Calf Pools

\begin{tabular}{lcc}
\hline & $f$ & $\%$ \\
\hline Sold to stockyards & 135 & 78.0 \\
Sold to broker & 38 & 22.0 \\
Sold freezer beef & 38 & 22.0 \\
Sold truckload & 11 & 6.4 \\
Videomarketing & 5 & 2.9 \\
Sold online & 1 & .6 \\
Other method of selling & 34 & 19.7 \\
\hline
\end{tabular}

Why did you not participate in 2005 or 2006?

Those respondents who reported that they did not participate in 2005 or 2006 were asked "Why did you not participate in the calf pool in 2005 or 2006?" Of the 17 responses, six participants reported that they had sold their cows, four individuals cited the requirements for participation as the reason for discontinuing participation, and three respondents attributed the costs of participating as a factor. Two respondents discontinued because the farmer chose to "Keep all my calves to grow out" and two other respondents discontinued due to dissatisfaction with the calf pool. Comments included: "The total cost per head was too high" and "I didn't like the way it was organized" (see Appendix D).

Advantages of Participation

Respondents were asked to "List three major advantages of participating in a calf pool." Three hundred eighty-six responses were received. Of those, 116 respondents 
(30.0\%) cited "price" as their major advantage, "By selling calves in truckloads we increase the possibility of receiving an above-market price" and 94 (24.4\%) responses included "management" as an advantage, one producer commenting, "I have better management of all aspects of my farm." Sixty-four responses (16.5\%) could be categorized under "convenience" such as "Selling all calves at once" "eliminates waiting in long lines" and "we purchase products together for better deals." Fifty-seven producers (14.8\%) reported that their major advantages had something to do with the quality of the calves they produced, several farmers stated, "Improved genetics and overall healthier herds." Fifty-one responses (13.2\%) were classified under "learning/fellowship" stating that he could "Get helpful knowledgeable assistance and feel less alone when it comes to marketing" (see Appendix B).

\section{Disadvantages of Participation}

Participants were asked, "List three major disadvantages of participating in a calf pool." Three hundred and ten responses were received. Of those, 93 respondents $(30 \%)$ referenced "time/convenience" as their major disadvantage, or, "too much time involved for the small premium over stockyard prices." Seventy responses (22.6\%) were related to "conformity within the group" and "Not having all the freedoms of being on your own." Fifty-eight comments (18.7\%) were classified under "cost" a major concern being "funding vaccines and feed out of your own pocket" Fifty-two producers (16.8\%) reported that "weaning" was the biggest disadvantage to participation in a calf pool, specifically, "additional risk associated with holding calves for weaning." Seventeen responses $(5.5 \%)$ were in reference to "price" expressing concerns that "buyers are still not willing to pay the premium price for preconditioned calves" and 16 responses $(5.2 \%)$ 
were directly related to "facilities," on example being "Not all pastures have good working facilities" (see Appendix C).

\section{Suggested Improvements to Calf Pools}

Participants were asked, "Calf pools could be improved by:” Two hundred thirtyeight replies were analyzed and 50 responses $(21 \%)$ were items directly related to “quality/organization" or more specifically, "continue to use performance-tested genetics" and "cooperation with each other." Forty-two respondents $(17.6 \%)$ thought the calf pool could be improved by "education" as one farmer stated, "we need to increase educational opportunities during our meetings." Forty-two producers (17.6\%) reported "flexibility" as the main improvement that could be made, especially, "being sure our vaccines are research-based" and "being more flexible with color/breed." Twenty-five (10.5\%) respondents cited "fellowship/communication" as an improvement, citing "better communication in pools statewide would make a difference." Twenty-four individuals $(10 \%)$ wanted "stricter rules," such as "upgrade all pools to the Gold standard" and "all pools should agree on a turn-out date for bulls." Seventeen statements $(7.1 \%)$ would like to see "more producers." Sixteen (6.7\%) thought the improvement could be made with “price," by "creating a definite higher market price," and $15(6.3 \%)$ believe that "more advertising" is the key to improving calf pools (see Appendix D). 


\section{CHAPTER V}

Summary, Conclusions, and Recommendations

\section{Statement of the Problem}

Over 250 farmers participate in West Virginia calf pools. In order to get more West Virginia farmers involved in the cooperative style of marketing, promoters must clearly convey the benefits and sacrifices of participation in the West Virginia calf pool program. However, no study has been conducted to examine the satisfaction of the farmers or their thoughts for the improvement of the program.

While recently attempting to create a calf pool in an area that was not familiar with the program, there were many questions raised by the beef cattle producers. Some of the most common questions included:

Do farmers involved in existing calf pools find it helpful?

Are they making more money?

Do they feel the extra work is worth the extra profit?

No one could answer those questions without consulting several producers and asking their opinions. Other counties starting calf pools appear to be having the same concerns and without the factual information those questions will remain unanswered. Purpose of the Study

The purpose of the study was to determine the perceptions of calf pool participants toward the West Virginia calf pool organization. Information obtained from this study will be used to document calf pool participants' perceptions toward the organization. 


\section{Objectives of the Study}

The primary objective of the study was to determine the perceptions which calf pool participants possess toward the West Virginia calf pool organization.

The specific objectives were:

1. To determine the number of years beef producers have participated in the calf pool.

2. To determine the types and numbers of animals marketed via the calf pool.

3. To determine what percentage of animals producers were marketing via the calf pool.

4. To determine whether producers desired to market more animals via the calf pool.

5. To determine the level of satisfaction of producers who participate in the calf pool.

6. To determine the benefits from participation in the calf pool.

7. To determine how the calf pool organization might be improved.

\section{Limitations to the Study}

The study is being limited to only beef producers involved with the calf pool organizations in West Virginia from 2000-2005. These producers are representative of calf pool producer participants in the state of West Virginia.

\section{Summary}

Approximately nine of out ten participants were male. There was one respondent under the age of 30. Nearly one-third of respondents were between 51 and 60 years of age, and another ten percent were over the age of 71 . Greater than $63 \%$ of respondents 
were over the age of 50. Nearly one-half of the producers who responded were full-time farmers. Greater than one-third of those who reported did utilize outside labor.

The average respondent to this survey was a male between the ages of 51 and 60 who produces approximately 56 calves per year. He markets 36 calves through the calf pool. The average producer is satisfied with the pool, plans to continue participation, and increase the number of animals he markets within the next five years.

Greater than ninety percent of participants expressed some level of agreement with the following statements: I have incurred additional costs as a result of participating in the calf pool, participation in the calf pool encouraged me to be a better manager, I receive above-market prices by participating in the calf pool, I will continue to participate in the calf pool, and I have become a better manager of my operation because of the calf pool. More than eighty percent agreed with the following statements: I am satisfied with the operation of my calf pool, as a result of the calf pool, I keep better records (birthdates, injections, etc.), and the benefits of participating in the calf pool are worth the expense, I implemented a recordkeeping system to track animals to include in the calf pool, As a result of the calf pool I have changed my feeding rations to increase growth of my animals, As a result of the calf pool, I observe my animals more closely for disease problems. More than sixty percent of participants agreed with the following statement: as a result of the calf pool I spend more time with my animals in calving season.

More than three-fourths of the respondents had participated in a calf pool in 2005 or 2006. Of those who did not, three-fourths had participated prior to 2005. More than half of participants reported that they plan to increase the number of calves they contribute to the calf pool in the next five years. 
When asked their marketing methods before the producer joined the calf pool, greater than three-fourths "sold to stockyards." Greater than one-fifth marked each: "sold to broker," and "sold freezer beef."

The top three major advantages to participating in a calf pool included: price (better price per pound), convenience (load all out in one day, shorter lines), and management (encouraged better recordkeeping). The top three major disadvantages to participating in a calf pool were: time/convenience (extra work to precondition), conformity within the group (too many rules), and costs (expensive to feed and vaccinate). The top three recommendations for improving the calf pool were directly related to: quality/organization (more meetings to make decisions), increasing flexibility (more freedom to manage), and education (programs to enhance learning).

\section{Conclusions}

Based on the results of this study, the following conclusions were drawn:

1. Greater than $90 \%$ of respondents reported that they plan to continue participation in the calf pool.

2. An overwhelming majority of respondents were male.

3. An overwhelming majority of respondents were over the age of fifty.

4. Greater than half of participants plan to increase the number of calves they market through a pool within the next five years.

5. Greater than $90 \%$ of participants felt that calf pools induced higher prices.

6. The average producer has increased the number of animals he markets through the calf pool. Our data shows that in the first year of participation, the average 
producer marketed 28 animals, while 2006 data shows that the average producer marketed 38 animals through the pool.

\section{Recommendations}

The following recommendations are based on the results of this study of the attitudes and perceptions of calf pool participants in West Virginia toward calf pool organizations.

1. It is recommended that additional research be conducted to determine the perceptions of calf pool producers in West Virginia toward calf pool organizations within 3-5 years.

2. It is recommended that additional research be conducted to determine the level of satisfaction calf pool participants have toward calf pool organization.

3. It is recommended that calf pool participants further explore more effective methods of recruiting additional producers and buyers.

4. It is recommended that additional research be conducted to determine other barriers that may affect calf pool organizations.

5. It is recommended that additional research be conducted to determine what impacts calf pools have on the feeder calf market in West Virginia.

6. It is recommended that additional research be conducted to determine if farmers who no longer sell through the calf pool are satisfied with their decision.

7. It is recommended that programs be conducted in West Virginia to educate beef cattle producers on calf markets and the benefits of the calf pool. 


\section{REFERENCES}

American Marketing Association. (2006). Definitions of marketing terms. Retrieved November 3, 2006, from http://www.marketingpower.com/mg-dictionary.php.

Ary, D., Jacobs, L. C., Razavieh, A. \& Sorenson, C. (2005). Introduction to research in education ( $7^{\text {th }}$ ed.). Belmont, CA: Thomas Wadsworth.

Avent, K., Ward, C., \& Lalman, D. (2002). Economic value of preconditioning feeder calves. Retrieved March 12, 2007, from http://osuextra.okstate.edu/pdfs/F583web.pdf.

Bartels, R. (1976). The history of marketing thought (Rev. ed.). Gorsuch: Gorsuch Scarisbrick.

Born, H. (2001). Keys to success in value-added agriculture. Retrieved December 12, 2006, from http://attra.ncat.org/attra-pub/keystosuccess.html.

Cattle Network. (2006). R-CALF: Ag secretary misstates international disease standards. Retrieved December 13, 2006, from http://www.cattlenetwork.com/content.asp?ContentID=57926.

Cox, G. (n.d.) People and the world's environment. Retrieved December 13, 2006, from http://www.psci.unt.edu/cox/Capstone/Environment.Outline.htm.

Hendrickson, S., \& Lehmkuhler, J. (2002). Preconditioning calves: evaluate the benefits. Retrieved March 12, 2007, from http://www.uwex.edu/ces/cwas/livestock/documents/preconditioningcalves2002.p df. 
Holt, J., Lord, E., \& Simpson, J. (2002). Florida cow-calf management, $2^{\text {nd }}$ editionmarketing feeder calves. Retrieved December 6, 2006, from http://edis.ifas.ufl.edu/BODY_AN122.

Huitt, W. (2004). Maslow's hierarchy of needs: Educational Psychology Interactive. Valdosta, GA: Valdosta State University. Retrieved March 2, 2007 from http://chiron.valdosta.edu/whuitt/col/regsys/maslow.html.

National Agricultural Statistics Service. (2007). United States Department of Agriculture Annual Report. Retrieved January 6, 2007, from http://www.nass.usda.gov/index.asp.

Noecker, N. (2003). Sell them for all they're worth. Retrieved December 12, 2006, from www.omafra.gov.on.ca/english/livestock/beef/facts/info_sellthem.htm.

Osborne, P. (1998) WV quality assurance feeder cattle sales. Retrieved December 5, 2006, from http://www.wvu.edu/ agexten./forglvst/qasales.htm.

Pennsylvania Beef Quality Assurance. (n.d.) Mid-Atlantic BQA Alliance. Retrieved December 13, 2006, from http://www.pa-bqa.org/Content/MidAtlantic.aspx.

Rasby, R. (2006). Beef cattle production frequently asked questions. Retrieved December 13, 2006, from http://beef.unl.edu/FAQ/200604020.shtml.

Reilly, T. (1989). Value-added selling techniques. New York: Contemporary Books. Rymer, E. (2006). Story of Farming. Retrieved March 1, 2007, from http://www.historylink101.com/lessons/farm-city/story-of-farming.htm.

Schmitz, E. (2003). Pooling Calves. Colorado State University Cooperative Extension Golden Plains Area. Retrieved March 20, 2007, from http://www.colostate.edu/Depts/CoopExt/GPA/pooling_calves.html. 
Townes, G. (2006). Barter: A Viable Alternative to Doing Business. Retrieved on March 12, 2007, from http://www.nfib.com/object/IO_27278.html.

US Department of Agriculture. (1982). Food- from farm to table. Washington, D.C.: US Government Printing Office. 
APPENDICES 
APPENDIX A

First Cover Letter 
January 3, 2007

\section{Dear Calf Pool Participant:}

Whether you are a charter member of your local calf pool or last year was your first year to participate, we are interested in your opinions. As someone who is involved in the calf pool process of marketing livestock, your opinions, views and experiences as a beef producer are important to the calf pool's success.

The purpose of this research study is to determine the attitudes of calf pool producers toward West Virginia calf pools. The results of this study will be used to prepare a thesis to partially fulfill the requirements for a Master of Science Degree in Agricultural and Extension Education. By completing this questionnaire, you will be contributing to the future growth of calf pools in West Virginia.

Participation in this research study, while voluntary, will only take a few minutes of your time. You may skip any questions you are not comfortable answering. Please be assured that all information will be kept as confidential as possible. Survey results will be reported in a summary format and individual responses will not be identifiable. You will notice a code number at the top right of the first page of the survey. This code will be used to identify non-respondents for follow-up and will be destroyed before the data are analyzed. Survey results will be reported in summary format and individual responses will not be identifiable.

A postage-paid self-addressed return envelope is provided for your convenience. Please return the completed survey before January 17, 2007. Please take a moment right now to fill out the survey and send it back to contribute your opinions to this statewide study. We sincerely appreciate your time and effort.

Sincerely,

Carrie M. Stemple

Graduate Student
Stacy A. Gartin

Professor 
APPENDIX B

Follow-up Cover Letter 
January 31, 2007

\section{Dear Calf Pool Participant:}

On January 3, we sent you a questionnaire about your participation in West Virginia calf pools. As of today, we have not received your reply; we are enclosing a second copy of the survey that we hope you will complete and return. If you have already returned the first one, there is no need to complete this one, and we sincerely appreciate your participation.

The purpose of this research study is to determine the attitudes of calf pool producers toward West Virginia calf pools. The results of this study will be used to prepare a thesis to partially fulfill the requirements for a Master of Science Degree in Agricultural and Extension Education. By completing this questionnaire, you will be contributing to the future growth of calf pools in West Virginia.

Participation in this research study, while voluntary, will only take a few minutes of your time. You may skip any questions you are not comfortable answering. Please be assured that all information will be kept as confidential as possible. Survey results will be reported in a summary format and individual responses will not be identifiable. You will notice a code number at the top right of the first page of the survey. This code will be used to identify non-respondents for follow-up and will be destroyed before the data are analyzed. Survey results will be reported in summary format and individual responses will not be identifiable.

A postage-paid self-addressed return envelope is provided for your convenience. Please return the completed survey before February 7, 2007. Please take a moment right now to fill out the survey and send it back to contribute your opinions to this statewide study. We sincerely appreciate your time and effort.

Sincerely,

Carrie M. Stemple

Graduate Student
Stacy A. Gartin

Professor 
APPENDIX C

Instrument 


\section{Attitudes of West Virginia Calf Pool Participants toward West Virginia Calf Pools}

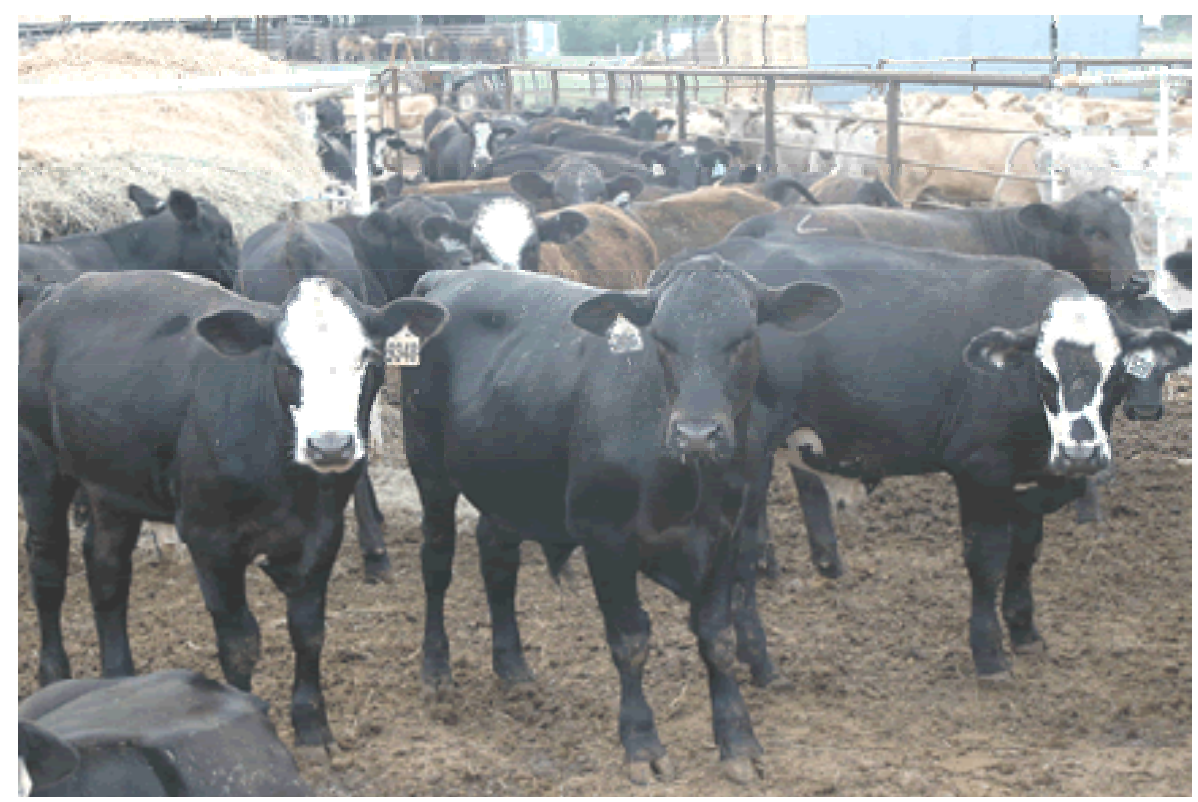

Carrie M. Stemple

Graduate Student

Agricultural and Extension Education

Davis College of Agriculture, Forestry, and Consumer Sciences

West Virginia University

Morgantown, WV 26506 
The purpose of the study is to determine the attitudes of calf pool producers toward West Virginia calf pools.

Please answer these questions to the best of your ability.

\section{Section I}

1. Did you participate in a calf pool in 2005 or $2006 ?$

Yes (proceed to question 4)

No (proceed to question 2)

2. Did you participate in a calf pool prior to 2005 or $2006 ?$

Yes (proceed to question 3)

No (Stop here, place this questionnaire in the envelope provided and return.

Thank you for your participation.)

3. Why did you not participate in the calf pool in 2005 or 2006 ?

4. How many years have you participated in a calf pool?

years 


\begin{tabular}{|l|l|l|l|l|}
\hline & \multicolumn{2}{|c|}{2005} & \multicolumn{2}{c|}{2006} \\
\cline { 2 - 5 } & steers & heifers & steers & heifers \\
\hline $\begin{array}{l}\text { 5. How many calves were born } \\
\text { on your farm in 2005 and } \\
2006 ?\end{array}$ & & & & \\
\hline $\begin{array}{l}\text { 6. How many calves were } \\
\text { purchased for resale through } \\
\text { the calf pool in 2005 and }\end{array}$ & & & & \\
2006? & & & & \\
\hline $\begin{array}{l}\text { 7. How many calves did you } \\
\text { contribute to calf pools in 2005 } \\
\text { and 2006? }\end{array}$ & & & & \\
\hline
\end{tabular}

8. How many calves did you contribute to calf pools the first year you participated? steers heifers

9. What is the maximum number of calves you could contribute to a calf pool given your current physical resources (land, labor and water)? calves

10. Do you plan to increase the number of calves you contribute to calf pools in the next five years?

Yes

11. Before you participated in the calf pool, how did you market your animals? Check all that apply.

a. Sold to local stockyards

b. Sold to a broker

c. Sold freezer beef

d. Personally organized and sold truckload of animals

e. Sold animals via videomarketing

f. Sold animals via the internet (online)

g. Other (please specify)

h. Other (please specify) 


\section{Section II}

Directions: Please indicate your level of agreement with the statement by circling the corresponding number

\begin{tabular}{|c|c|c|c|c|c|c|}
\hline . & 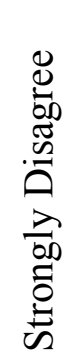 & 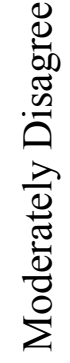 & 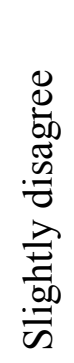 & 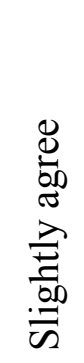 & 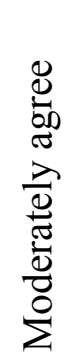 & 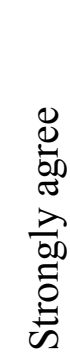 \\
\hline $\begin{array}{l}\text { 1. I am satisfied with the } \\
\text { operation of my calf } \\
\text { pool. }\end{array}$ & 1 & 2 & 3 & 4 & 5 & 6 \\
\hline $\begin{array}{l}\text { 2. Participation in the } \\
\text { calf pool has } \\
\text { encouraged me to be a } \\
\text { better manager. }\end{array}$ & 1 & 2 & 3 & 4 & 5 & 6 \\
\hline $\begin{array}{l}\text { 3. As a result of the calf } \\
\text { pool I have become a } \\
\text { better manager of my } \\
\text { operation. }\end{array}$ & 1 & 2 & 3 & 4 & 5 & 6 \\
\hline $\begin{array}{l}\text { 4. As a result of the calf } \\
\text { pool I observe my } \\
\text { animals more closely } \\
\text { for disease problems. }\end{array}$ & 1 & 2 & 3 & 4 & 5 & 6 \\
\hline $\begin{array}{l}\text { 5. As a result of the calf } \\
\text { pool I spend more time } \\
\text { with my animals in } \\
\text { calving season. }\end{array}$ & 1 & 2 & 3 & 4 & 5 & 6 \\
\hline $\begin{array}{l}\text { 6. As a result of the calf } \\
\text { pool, I keep better } \\
\text { records (birthdates, } \\
\text { injections, etc.) }\end{array}$ & 1 & 2 & 3 & 4 & 5 & 6 \\
\hline
\end{tabular}




\begin{tabular}{|c|c|c|c|c|c|c|}
\hline & 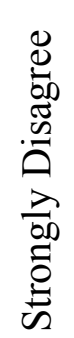 & 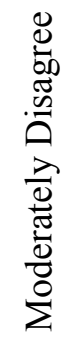 & 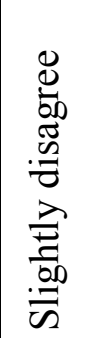 & 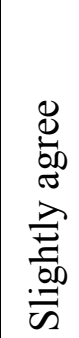 & 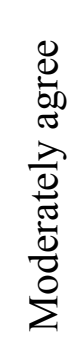 & 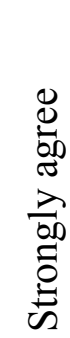 \\
\hline $\begin{array}{l}\text { 7. As a result of the calf } \\
\text { pool I have changed } \\
\text { my feeding rations to } \\
\text { increase growth of the } \\
\text { animals. }\end{array}$ & 1 & 2 & 3 & 4 & 5 & 6 \\
\hline $\begin{array}{l}\text { 8. I receive above- } \\
\text { market prices by } \\
\text { participating in the calf } \\
\text { pool. }\end{array}$ & 1 & 2 & 3 & 4 & 5 & 6 \\
\hline $\begin{array}{l}\text { 9. I implemented a } \\
\text { recordkeeping system } \\
\text { to track animals to } \\
\text { include in the calf } \\
\text { pool. }\end{array}$ & 1 & 2 & 3 & 4 & 5 & 6 \\
\hline $\begin{array}{l}\text { 10. I have incurred } \\
\text { additional costs as a } \\
\text { result of participating } \\
\text { in the calf pool. }\end{array}$ & 1 & 2 & 3 & 4 & 5 & 6 \\
\hline $\begin{array}{l}\text { 11. The benefits of } \\
\text { participating in the calf } \\
\text { pool are worth the } \\
\text { expense. }\end{array}$ & 1 & 2 & 3 & 4 & 5 & 6 \\
\hline $\begin{array}{l}\text { 12. I will continue to } \\
\text { participate in a calf } \\
\text { pool. }\end{array}$ & 1 & 2 & 3 & 4 & 5 & 6 \\
\hline
\end{tabular}


List three major advantages of participating in a calf pool.

1.

2.

3.

List three major disadvantages of participating in a calf pool.

1.

2.

3.

Calf pools could be improved by:

1.

2.

3. 


\section{Section III}

\section{Demographics:}

1. What is your gender?
a. Male
b. Female

2. Using the following categories, please indicate your age.

a. Under 21 years of age

b. 21-30 years of age

c. 31-40 years of age

d. 41-50 years of age

e. 51-60 years of age

f. 61-70 years of age

g. Over 71 years of age

3. How many brood cows and heifers do you have to calve this spring?

4. What is your role in the farming operation?
a. Full-time farmer
b. Part-time farmer

5. Do you utilize outside labor?

Yes

6. Which calf pool(s) do you contribute to? Mark all that apply.

a. Monroe-Greenbrier

b. Barbour

c. Tyler

d. Randolph-Tucker

e. Morgantown

f. Pendleton-Hampshire

g. Central

h. Nicholas-Fayette

i. Jackson-Mason

j. Wirt

k. Marshall-Ohio

1. Other (please specify) 
Comments:

If you have questions about the survey, please contact me at carrie.stemple@mail.wvu.edu or call (304)329-1391.

Thank you for taking the time to complete this survey! 
APPENDIX D

Open-Ended Responses

"Why did you not participate in a calf pool in 2005 or $2006 ?$ 
Open Ended Responses: Question 3

"Why did you not participate in a calf pool in 2005 or 2006?"

Open-Ended Responses:

If a response was received more than once, the number of times it was received is included in parentheses following the response.

For the time and money that was put into the calves in feed and vaccinations, they did not sell much better than the calves at a local sale.

The total cost per head is too high. And I don't like some of the ways it is done.

Too much expense! And saw no benefit to it. The extra money you get for your calves doesn't make up for the extra money you have to put in them.

I sold calves in the pre-vaccinated sale at Weston

Kept all calves to grow out

My cattle always sold last after a 3-4 hour sale and many of the buyers had left by that time.

One producer grew large enough to sell his calves as an individual producer, leaving too few calves to continue our pool.

Because I raise full-blooded RED Limousin cattle, and the calf pool in Roane Co. and WV are black angus lovers, and I can't stand Angus cattle. I sell my calves to Laura's Lean Beef for more money/lb. Until the pool quits requiring members to us Blk Angus

Calves were bigger than they would take.

The requirements were too complicated (weights, meds, weaning etc.) and time consuming in view of the small number of animals I have.

Was not ready to participate. Plan to participate in 2007

Had an operation and could no longer attend a herd.

Mainly because of labor shortage on farm. There also was some dissatisfaction with weigh up.

Sold cows.

Sold cows- cows were 13-17 years. Market was high then. Will wait until market drops and buy. 
When I reached the age of 80 I sold my cows because I had no help.

Working away from home 
APPENDIX E

Open-Ended Questions

"Before you participated in the calf pool, how did you market your animals? Check all that apply." 


\section{Open-Ended Questions: Question 11}

"Before you participated in the calf pool, how did you market your animals? Check all that apply."

Open-Ended Responses:

If a response was received more than once, the number of times it was received is included in parentheses following the response.

Background and sold yearlings

Backgrounders (2)

Local background farmer (3)

Retained ownership (2)

Sold to feedlot (5)

WV feedlot program

Farmer involved with the calf pool

In field

Individuals (2)

Off farm

On farm through newspaper and market bulleting

Rick Garrett, C.D. Cole

Sold as yearlings

Sold in field

Private contract (5)

Feeder calf sales (3)

State graded feeder calf sales (2)

Headwater Farm Project 


\section{APPENDIX F}

\section{Open-Ended Questions}

"List three major advantages of participating in a calf pool." 
Open-Ended Questions: Question 3-1

"List three major advantages of participating in a calf pool."

Open-Ended Responses:

If a response was received more than once, the number of times it was received is included in parentheses following the response.

\section{Responses classified under "Price":}

A better way to market my calves.

Ability to market cattle in load lots. (7)

Ability to purchase replacement heifers from fellow producers.

Able to market all of calves at one time (steers one time, heifers next). (9)

Better prices on feed and medicine by buying as a group. (10)

Calf pickup closer than local markets.

Calves graded on the farm.

Can move bigger animals.

Close to market calves.

Collect all calves.

Collection point close to farm.

Ease of selling.

Easy delivery of calves to market.

Eliminates waiting in line at stockyards for feeder calf sales (10)

Fairly well organized.

Hauling. (10)

Reduced feed costs for cows/earlier weaning.

Sell calves while calves are still on the farm. 
Sell on a sale with many different buyers from a large area.

Selling lots of cattle in $50 \mathrm{lb}$ brackets all alike.

Timely payment for calves.

Uniform groups of calves being sold.

\section{Responses classified under "Learning/Fellowship"}

Advantages of discussions with other producers thus deriving new ideas and fellowship.

Assistance from extension office and authorities. (7)

Associated local recognition.

Cooperation between pool members when working cattle, thus sharing labor.

Enjoy fellowship with other farmers.

Information which has helped me to be more efficient in managing my herd's structure and health.

Learn new and better management skills. (4)

More performance information about our animals. (6)

Provides "education" to become a better farmer. (2)

Shared information which has enabled me to expand my knowledge of industry needs. (2)

Work with other farmers to share ideas that work better. (7)

Responses classified under "Management"

Better gain/weight on calves sold. (6)

Better management of herd is encouraged and essentially required. (15)

Better marketing. (8)

Better record keeping. (16) 
Better vaccination program. (20)

Can more closely monitor calf performance and obtain carcass data at times.

Early weaning allows body condition score to improve on cows going into winter. (7)

Have a better way to decide to cull cattle.

Have a large amount of calves available so get my buyers together sometime.

Have been able to track calves to slaughter.

I want to increase the number of calves to make it more worthwhile financially and work per calf.

Increased record keeping. (3)

It's a plan- you need one.

Large group sales.

Less stress on animals and owners. (6)

Makes me a better observer of my operation.

More communication with other producers.

More systematic herd management. (pasture rotation, etc.)

Organizational plan: weaning date, vacc. Schedule

Producers are forced to more closely examine all practices (bull selection, culling, time of calving, recordkeeping).

\section{Responses classified under "Price"}

Better prices from selling through pool. (38)

Commission is lower than regular sale. (3)

Do get premium on part of cattle. (3)

Future price $=$ premium for BQA, weaned, source-verified calves.

Higher price for our cattle. (30) 
More buyers. (3)

More competition.

Networking to market a more favorable product for a more favorable price.

One price for group of animals.

Per pound of calf is higher than market.

Possibility of better calf prices.

Price. (25)

Probably will have better prices for the future also.

Secure higher prices over longhaul.

Selling more pounds.

The length of time.

They all bring the same price.

Trailer load lots helps price

When cattle are cheap that's when it really pays off.

You receive premiums for buying tested bulls and having greater calves.

\section{Responses classified under "Quality”}

Ability to be compensated for weaning.

Able to expose genetic potential through 45 day feeding period.

Better breeding stock used. (9)

Better herd evaluation- improved selection process. (4)

Better quality pen together.

Build a reputation for quality cattle. (8)

Even weights of calves. 
Future market demand for our calves.

Gentler calves.

Get better weights.

Good calves for buyers.

Graded by state grader each year.

Has made our cattle more uniform. (5)

Higher selling weights.

I can get some records on how calves did after they are in feed lot.

More weight gain.

Performance.

Producing a good product, better genetics.

Producing a product that is healthier and can stand stress better.

Provides premium price for top of the line calves.

Providing feeders with quality and healthy calves.

Quality cattle.

Same buyers come back to buy cattle year after year.

Shipping a quality product.

Upgrading light calves.

Volume of cattle to help attract buyers.

Weaning and preconditioned calves allows cows in herd to be healthier. (8)

Weight.

When calves go to feedlots due to preweaning calves are ready to go as for eating from bunk feeders and vaccinations.

You breed better quality calves that will grow and yield and quality grade. 
APPENDIX G

Open-Ended Questions

"List three major disadvantages of participating in the calf pool." 
Open-Ended Questions: Question 3-2

"List three major disadvantages of participating in the calf pool."

Open-Ended Responses:

If a response was received more than once, the number of times it was received is included in parentheses following the response.

\section{Responses classified under "Conformity"}

A farmer is usually an independent person but being in a group and in a pool is all pluses

Can not sell all calves at the same time. (7)

Committed to sell with majority of group. (17)

Dealing with different and strong personalities. (19)

Exposure to other farmers led to increased learning.

Feedlot alliances should be developed to offer a price to accept or reject before stockyard commitment.

Having to rely on the credibility of the others when your cattle are consigned.

I don't like other people telling me what kind of cattle to raise.

I don't think everyone keeps as good a care of their calves as we do.

I don't want other people pricing my cattle.

I have always raised the best cattle and followed good farming practices!

Improved communications.

Inconsistent communication from leadership.

Leaders of calf pools discriminate against producers with Herefords.

Maintaining integrity.

Market most calves at the same time (hard to find enough labor to round up 250 hd in 2-3 days).

More meetings. 
More requirement of fall grazing.

Not being told up front by pres. and county agents what is going on from meetings. they've gone to.

Not having all the freedoms of being on your own.

Our sale date is too late.

Quality of calves vary from farm to farm.

Smaller producers do not stand to gain as much as larger producers.

Some concerns about health programs varying from farm to farm.

Strongly disagreed with angus breeding.

Too many people tracking from one farm to another.

Too many vaccinations, not search based.

You must work harder to keep good records, breeding, birthdates, etc.

Active conscientious participants carry the dead wood.

Co-mingling can be a problem in some large pools

\section{Responses classified under "Cost”}

1st year your startup is more expensive than taking cattle to the stockyard w/o preweaning.

Added cost for vaccine.(3)

Additional travel costs.

Associated costs.

Conflicts of time.

Cost (9)

Expense (6)

extra cost (12) 
Representing your pool.

Gold-feed cost and time.

Have to put out more of your own money for feed, vacc. Labor.

Higher expenses. (4)

Increased cost. (11)

It does have substantial cash outlay.

More money in time, feed and vaccinations than the return.

Purchase of performance bull for small number of cattle.

Some years cost of feed is very expensive.

The extra costs and time required to participate, however, I believe that the disadvantages has been more than offset by the advantages.

\section{Responses classified under "Facilities"}

Extra facilities needed. (6)

Getting a place to put them in a trailer.

Had a poor loading place- too muddy.

Hauling calves to be weighed and weaned to other locations.

Increase need for weaning lots. (3)

No place to sell out calves.

Requirement of two vaccinations, one before weaning. Not all pastures have.

Shipping location too far, 75 miles.

Slightly longer haul to a loading facility.

Trucking- distance to scales. 


\section{Responses under "Price"}

Buyers are still generally not willing to pay a significant additional price (above market) for preconditioned calves. (3)

I didn't receive premium from input incurred.

Good quality, properly managed calves receive the same price as low quality, mismanaged calves.

Marginal value added compared to local sales. (3)

Negotiation of price is not possible.

Not knowing what your calves will bring until you have bought everything.

People that sell on the end of the sale always get lower prices.

Producers are not receiving a premium for all the extra work and expense.

Small lots (not full tractor loads) bring less money.

The auctioneer does a poor job of selling our cattle.

The prices we receive are not all that great compared to the work we have to put into everything.

There are too many calves sold on the same day.

Weaned bunk broke calves are sold at the same time and price as bawling calves.

When the cattle market is high we do not seem to receive a premium for our BQA calves.

\section{Responses under "Time/Convenience"}

Additional input of time is substantial and could be prohibitive.

Associated time.

Buyers want to be sure they have their trucks loaded.

Calves are stressed by over-sorting on load day.

Delivery to central location vs. pickup at farm. 
Don't see the calves sell.

Extra hauling.

Extra labor. (4)

Extra records.

Extra risk.

Extra time and labor rounding up cattle for 2 vaccinations.

Feed chosen by pool not always available when needed even though I and pool have made arrangements.

For me, mileage to meetings and hauling to pickup point.

Grading done when calves are just weaned- can change a lot in 4 weeks.

Handling calves two times.

Hauling distance.

Have to sell and transport on two separate days.

Having short notice to get to the scales for delivery

Health issues associated with weaning, shipping fever, etc.

I have to vaccinate the calves 2 times.

Increase in labor.

Increase in time.

Increased accountability.

Increased labor. (3)

Instead of just dropping cattle off at market turns into 2 or 3 days work to sell.

It is time consuming.

Keeping records in greater detail.

Labor. 
Labor after weaning.

Labor $=$ records, cattle processing, expence, EID, preconditioning.

Load out day is work.

More and more records, need simple record-keeping charts.

More care of bad eyes.

More labor. (8)

More paperwork.

More record keeping.

More stress on calves pre truckload.

More time consuming. (3)

More work. (11)

Much more labor involved.

Need for additional help in working cattle. No longer a one-man operation.

Not getting any carcass data feedback from buyers to help improve our herd.

Numbers on cattle from killers and packers.

Poor sale order.

Records. (2)

Sale of all calves.

Sale time.

Same people do all the work year after year.

Shots.

Spend more time with your animals.

Start preparation in August. 
The calves eat a lot of grass that I could use for cows.

The catching and gathering calves twice for vaccines.(3)

Time consuming. (3)

Time- too much time involved for the amount of extra money over stockyard.

Timing for participating in fairs and other events when not in hay.

Too much work on the feeding end.

Transportation to load sites.

Travel distance/time to meeting/deliver location.

Trucking, 60 miles one way.

Twice getting in to vaccinate.

Very little performance data back from buyers/feedlots.

Working with order buyers instead of farmer feeders in feedlots directly.

Workload.

\section{Responses under "Weaning"}

45 day weaning.

90 day feeding.

A lot of extra labor weaning and vaccination costs.

Additional risk associated with weaning and keeping the calves longer.

Better facilities to wean.

Calves stay longer.

Extra cattle handling for vaccinations and weaning.

Extra labor and expense of 45 day weaning period. (4)

Extra time in weaning calves. 
Extra work in shots, weaning, grading cattle.

Feeding and taking care of the calves for 45 days or more, also ties up barn and cow lot space.

Feeding calves for 60 days.

Gain after weaning.

Having the facilities to hold your calves for 45 days before shipping.

Having to wean calves in a 10 day window and then getting them back in for boosters.

Holding calves longer.

I have to feed them for 45 days.

Inward labor to feed calves after weaning.

Loss of weight due to weaning.

Lot of extra work to background cattle for 60 days.

More risk by holding the calves an extra 45 days.

More time in the weaning process.

Must keep cattle confined longer.

Must put calves through chute too many times.

Requires a much longer daily feeding schedule right through winter.

Risk of losing a calf during early weaning.

Time feeding and working with calves.

Time they are on feed is too long. (4)

Too much grain in place of grass.

Weaned for too long of period, bulls need to be performance tested, results of finished products often result of feeding program, not genetic potential.

Weaning- extra work feeding. (7) 
Weighing of calves several times creates extra work.

Weight lost during weaning plus feed to gain weight back does not pay out. 
APPENDIX H

Open-Ended Questions

"Calf pools could be improved by:" 
Open-Ended Questions: Question 3-3

"Calf pools could be improved by:"

Open-Ended Responses:

If a response was received more than once, the number of times it was received is included in parentheses following the response.

\section{Responses classified under "Advertising”}

Advertising program.

Agriculture dept more involved.

Always looking to that added edge over the other markets.

Attracting more potential buyers.

Better advertising of cattle to be sold.

Better marketing of our cattle.

Better marketing to get more participation from various older buyers.

Calves should be grouped for $\mathrm{CAB}$ marketing- currently $\mathrm{CAB}$ is the leader in beef marketing on a national level.

Contact more buyers before sale.

Developing a mindset to obtain customers.

Having additional buyers on hand to compete.

Having more and better advertisement of sale of cattle.

More advertisement of the quality that we are producing.

More advertising and if pool calves are healthier in the feedlot than stockyard calves.

Show the buyers the data and expound on it.

More vigorous marketing of animals. 


\section{Responses classified under "Conformity"}

All members should do the same thing to the rules.

All pools participate in a joint advertising campaign to reach more buyers.

All pools statewide using the same vaccines during weaning.

Be angus based. I don't get paid for my genetics.

\section{Responses classified under "Education"}

Being able to acquire carcass data.

Better follow-up.

Better gains on grain feed.

Better genetics. (2)

Better system to predict sale weights.

Buyers to return carcass data to producers. (4)

Calves weighing more.

Continuing education workshops.

Develop a total herd health program for all pool members.

Additional help from extension at meetings.

Dissemination of education information regarding herd improvement.

Each pool is different with different profiles, but getting the buyers educated on what a good product or group of calves we have is the most important thing that WVU could strive to do.

Feedback- where are my calves, are they healthy?

Get more information back from the cattle when fed, performance, ribeye and grades.

Getting buyers more informed about what they are buying or what the warranty is.

Getting carcass data back from packers to better improve our herds.

Going to other producers in and outside of pool to better educate all. 
Having information on bigger buyer pool for calves.

Increase educational opportunities especially on feeding calves after weaning.

Insure we get kill/harvest data so we see the end product of our calves.

Members need to be shown how the pool helps them.

More and better communication to other producers not yet participating concerning advantages/disadvantages of calf pool participation (our pool has not grown in number of producers in its entire 8 year history, only original members participate.

More concerted effort to obtain and use carcass data.

More data on performance returned to producers.

More follow up as to who bought and where they went, how they fed out.

More followup of cattle after they're sold, Feedback from buyers.

More information on feed from pool numbers or gain for cost of pounds put on.

More mailing information to other farmers unfamiliar with pools through local agencies.

More negotiation and education with buyers, cattle company and packers when cattle are sold to be finished out.

More slaughter and feed data from buyer.

Need to have more meetings to keep everyone informed what is going on.

Receiving information on how they did in feedlot.

Requiring buyers that feed the calves out to provide carcass information.

Sell back to farmers in pool. This would improve our cattle.

Specifics on calf growth.

Stronger networks between the calf pools for more uniformity which could only improve everyone's calf pool returns.

That's tough, the main thing is cooperation and organization.

Using our carcass data to prove our calves are worth more. 
We have very good communication from our folks in charge.

\section{Responses classified under "Fellowship/Communication"}

Better communications. (3)

Better cooperation. (2)

Better organized.

Better statewide communication between pools concerning all facets of production (not just costs and price)

Better understanding by all members of what the pools are all about.

Better understanding of selling process.

Better understanding of the price slides and deductions due to overweight calves.

Buyers following through on what they want.

Cannot comment in general, always room for improvement.

Helping each other.

Honesty.

I think our calf pool works pretty well.

It's very important for everyone to be progressive-minded. Think way ahead and out of the box.

Less commission for bonding agent.

Less competition between the pools to get the best price.

Marketing cost, weigh bill, etc.

Maybe certain buyers have problems obtaining trucks on one certain day, then they need more time on pickup dates.

More government help.

Most pools are in a constant state of improvement. 
My pool is as good as you could ask for, everyone gets along well. No need for improvement.

Need more communication from pool manager.

Utilizing modern technology for auctioning.

We never really know what is going on with the other members that affect the pool.

\section{Responses classified under "Flexibility"}

Accept 400 pound calves.

Accepting calves other than blacks.

After the sale take calves up earlier.

Allow farmers to withdraw calves at any time from calf pool.

Being open to reasonable change.

Both vaccinations after weaning.

by giving pool members choices and let us decide what we want to do.

By including other breeds of good cattle instead of DAM Blk Angus.

by letting pool members decide what we want to do, not what WVU wants us to do.

Changing sale dates.

Cross breeding.

Cutting feed costs.

Don't get mixed up with less important details (bull turn out dates).

Earlier sale in fall.

Everyone needs to keep an open mind to better the pool.

Farmers selling calves to buyers out of the field, only has to pay a weigh bill on calves.

Find a sponsor to provide or finance lunch for calf loadout days. 
For 2007 we may want to wean on grass due to corn prices.

Having a later sale in addition to current one- sell only heavy feeders.

I'm not sure all vaccines are necessary.

Increased marketing opportunities for producers who purchase calf pool cattle.

Larger numbers.

Later pickup on calves.

Less requirements on cow herds, not many are research based.

Less than 45 days for feeding after early weaning.

Less vaccines.

Looking at different drug companies.

Marketing calves of alternate colors (red, white, etc.) in groups.

More flexible regarding breeds.

Need more genetic improvement through the use of crossbreeding.

No color discrimination.

Pool dates other time of the year to allow for better spring calving dates.

Possibly changing sale date.

Putting together smaller weights. Our smaller calves are penalized.

Sell all calves regardless of weight.

Selling calves earlier, keeping the same delivery. (2)

Selling calves in the same day (both sexes).

Shorter weaning time.

Smaller groups.

Lighter weights I think would sell to local producers should they be put together. 
Spring and fall sales in the same year.

Tighter weights on calf groups instead of advertising the 400-550 groups maybe advertise these groups with a 75-100 \# span.

\section{Responses classified under "More Producers"}

Additional participation of new producers.

All producers helping when cattle are being loaded out.

An easier way for new members to receive both the book and chuteside training (development of some type of dummy cow to give shots to.)

Be more producer-oriented.

Convincing more good producers to join in.

Get more producers in the calf pool.

Getting more farmers to participate.

Increasing size of calf pools.

More area farmers could participate.

More buyers.

More calves. (7)

\section{Responses classified under "Price"}

A little less commission.

A lot of cattle have been purchased at $\$ 1.25$ and sold around $\$ 1.00$. Heifers in particular. That's nothing as it should be worked on.

Better calf prices.

Better calf prices that reflect the additional labor involved and the quality of the product.

Better price- should have a larger spread between pool calves and stockyard calves. 
A larger price differential between pool and sale barn calves.

Better prices for calves.

By having buyers pay 10 to 15 cents above local calf prices.

Cost are starting to nickel and dime us to death: eartag, EID.

Creating definite higher market price.

For buyers to pay more premiums for weaned and vaccinated calves.

Have buyers put a contract on prices of calves at various weights on steer and heifer calves.

Haven't always got better pay for better cattle.

Higher premium for calf pool advantages to buyers.

Higher prices at sale.

Higher prices compared to stockyards.

Receiving better prices.

\section{Responses classified under “Quality/Organization”}

Better facilities needed at pickup point for pool calves.

Better grading.

Better place to sell calves.

Better quality.

Better quality of bulls (2)

Better run in the pool.

Centralized shipping point.

Clarification on directions of pickup sites.

Closer cooperation with WVU. 
Concise information to participants.

Consistent breeding philosophy.

Consolidating pools.

Continue to expand on and improve as we go.

Continue to improve on the quality of calves.

Continue to work with WVU and extension services.

Continuing to make sure that we produce high quality calves that grow, and grade without sickness.

Cooperation among members, state grader and farmer, us and buyers.

Cooperation of other farmers.

Doing a better job of estimating weight of cattle being sold.

Everyone contributing equally to the work required on loading days.

Genetics.

Get rid of our auctioneer.

Grading and pooling out calves.

Grading of calves. Grade age small not even looked at.

Have a better working relationship with producer.

Have vaccinations and ear tags when calves are graded the first time.

Having a better system of tracking calves through feedlots.

Having grader and rep on the same page.

Having the buyer pay for vaccinations and feed, ear tags, etc.

Having their own loading facility.

I hope we will continue to have a facility to hold sale. 
Increased experts for source verified cattle.

Increased use of performance-tested genetics.

Instead of trying to sell 5000 head on one day, sell 2500 each day.

Keep the best heifers pool-wide.

Limit number of members in conjunction to facility you load at.

Make one time getting in do it all at once.

More communications.

More consistent product $=$ better quality calves .

Need a good facility for calf pool loadout.

Need better grading.

Need to come up with a better and more permanent way of shipping cattle.

Reducing the cost of sales middle-men.

Replacing the auctioneer.

Some weight.

Tags being delivered before calving starts.

Visiting cattle near the end of the feeding period to see successes and faults (everyone needs to see the cattle).

Water and feed calves before trucking.

We may need our own loading facility.

WV extension people get too zealous.

\section{Responses classified under "Stricter Rules”}

Feedlot data, ADG feed conversion, etc. No "order buyers."

Ability to kick out producers who are problems. 
Farming a strict set long and short term goals.

Get everyone selling evenly aged cattle.

Make all pool be the Gold standard in WV.

Make sure sales are final, not more weigh day for auctions.

Meeting of pool members for improving bull and cow operation.

Members need to agree on a common date to turn bulls out.

More consistency in managing feed and medicine.

No resale calves should be allowed to be sold as a pool calf.

Objectives of pool and strategies to achieve them.

Producers agreeing on cow size and type, more consistent calves.

Requiring all participants to use all modified live vaccines.

Set higher quality standards in some pools.

Showing less favoritism to certain pools in sale order.

Strict rules.

Uniform in all pools in state.

Using common genetics.

Using only calves born and raised on your farm.

Using quality calves, no subs.

Voting rights within pool should be based upon number of calves sold in previous years sale. 
APPENDIX I

\section{Open-Ended Questions}

"Which calf pool(s) do you contribute to? Mark all that apply." 
Open-Ended Questions: Question 3-6

"Which calf pool(s) do you contribute to? Mark all that apply." Open-Ended Responses:

Creed Ward

Queen

RJ Rohr

Rohr

Upshur

PA feeder cattle roundup

Roane 
APPENDIX J

Comments 


\section{Open-Ended Questions: Comments}

"Keep up the good work!" Improve on marketing our cattle. Keep the best heifer all farm operation (certified heifers) Sell back to farmer in pool. ID All calves, birth date, etc.

All calf pools need to take lessons from Jackson and Mason county calf pools. They work together as team effort. That is where the money is. You have to work together. You also need to go by your bylaws made by your calf pool members.

Buyers want preconditioned calves but do not pay adequate premiums for the risk that producers take to wean, background, and hold calves to set pickup date.

Calf pooling is a great way for small herd owners to sell our cattle. However, you must make sure it is fair to sellers as well as buyer. It if continues so such as it is it will soon end.

Calf pools are (in my opinion) too expensive to participate in.

Calf pools are a great improvement for obtaining a premium price for cattle that are BQA certified and performance oriented.

Calf pools eliminate middlemen so producers can gain that share of profit. The farmer also receives some education of cattle history.

Communicate.

Disadvantages listed are inconvenience, not as criticisms. I feel that the advantages outweigh the disadvantages.

Due to injury and some health problems, I have reduced my herd to pay bills. I'm back to work and my health is better and I'm planning to expand my herd.

Farmers know how to raise calves; they simply need help with marketing.

For many years I had 25 calves ready for sale. I really enjoyed the cattle and watching the calves.

I don't remember ever making a profit. A good year was when I recovered my expenses.

Good luck in your work and education, and your degree in Agriculture.

I already was keeping records on the herd prior to the calf pool. I use AHIR through the American Angus Assoc. so I have to have birth dates and weights.

I am very proud to be part of this calf pool and plan to sell calves through it as long as I can. 
I do support and believe in the calf pool.

I feel good participating in pool and working with Phil Osborne

I feel the grading is the worst thing I have to deal with. Usually they take all the steers and some of the best heifers for a couple of years the same bull and same cows 2nd year all calves are M1. The next year 1/3 won't grade!?!

I have always tried to keep a close eye on my animals. I try especially to keep a close check on cows during calving season. The calf pool didn't change that. It gets frustrating when you do all the extra work to produce a better product.

I have been with my pool since its beginning. I am very proud of its success. I have had anywhere from 25-75 cows at different times. Our cattle since the beginning have always been higher and made more money than our neighbors cattle who didn't participate.

I really appreciate the opportunity to supply this information and hope to hear about the results of your work later. Thanks!

I think this is important research, and I hope the results will be disseminated to all those concerned when completed.

I will not participate in the calf pool in 2007. Not enough difference in prices to justify the time, effort and costs.

I would like to have a copy of the results of this survey. 2) How can people buy calves to put in the pool when all calves are to be born on owner's farm? 3) This is a good survey, other items may have been addressed are: (a) How do you feel about IED tags?

I would really appreciate return response as to how the summary turns out.

Increase in price does not cover increase in additional cost and labor.

Let county agents know the results of this survey. Thanks!

Our pool needs to get larger so more loads can be sold. I lose money every year on fast gaining and late calves that don't fit our loads.

Overall the calf pools I believe have been a valuable tool for the members.

Overall, I am happy with our pool operation. It seems to improve as each year progresses. I believe it is the right way to go as we enter the age of tracking calves.

Pools are the best marketing system for cattle since the start of demonstrational sales in the 1930 's. 
Thank you for asking me about my comments. I think the calf pool is the best way to market feeder calves. I have tried many different ways of marketing calves and the calf pool payoff through prices and quality. I have been on both sides of the calf pool.

The calf pool is a great idea for small farmers. My calves bring $\$ 100-\$ 150$ dollars more per head!

The calves should not be weaned as early. The stress on the younger calves is higher putting them at higher risk. Feed bill is too high for the sale price of the calves.

The fact that we sell calves through a calf pool did not make the care of our cattle or the goal of our operations anymore rigid. We had our first AI calf in 1947 and are still trying to get better. The calf pool has helped the price of the good $6 \& 7 \mathrm{wt}$.

The picture on the front of this paper of some fine boned slick haired southern cattle in a stockyard is not appropriate to promote WV feeder cattle and our calf pool.

There is considerable time and energy put into this way because of the feeding. Try new marketing tech- superior livestock TV, incorporate performance testing of calves with history on each cow to help producers select cows or heifer to cull or keep.

We are a small farm. Many of the negative aspects come from the fact I am currently working more than one job and farming. Due to the farms in this area we are unable to pool with anyone locally. Most of the small operators have mixed cattle of various colors.

We need to speak positively about other pools as this will benefit everyone!

We tried pools but it didn't work out because you can get as much at the stockyard as you can in the pool. We have a good health program and weaning schedule now.

Would like the results mailed to me.

Would you please share this information with us once you have compiled it into a usable format, maybe through the agents or Phil. Thanks. 
VITA

Carrie M. Stemple

Education:

Professional Experience:
May 2007

May 2005

June 2003 - February 2004$$
\text { January } 2005 \text { - May } 2006
$$

July 2005 - Present

\author{
Masters of Science \\ Agricultural and Extension \\ Education \\ West Virginia University \\ Morgantown, West Virginia \\ Bachelors of Science \\ Agribusiness and Rural \\ Development \\ West Virginia University \\ Morgantown, West Virginia
}

Program Assistant- Agriculture

WVU Extension Service

Preston County

Kingwood, West Virginia

Teaching Assistant

Division of Agricultural Education

West Virginia University

Morgantown, West Virginia

Visiting Instructor- Agriculture

WVU Extension Service

Preston County

Kingwood, West Virginia 